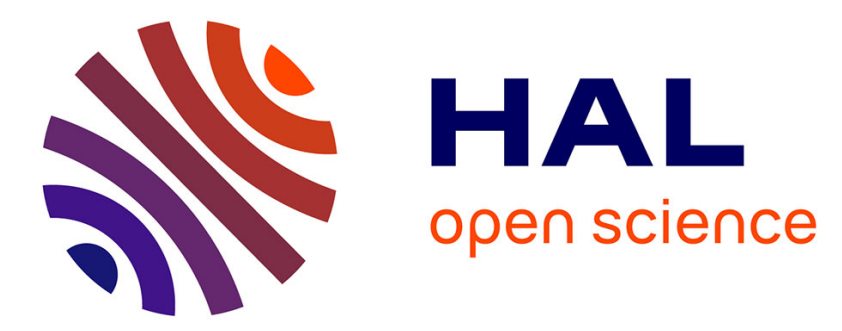

\title{
Application of LA ICP-MS analysis of arsenopyrite to gold metallogeny of the Meguma Terrane, Nova Scotia, Canada
}

\author{
Blandine Gourcerol, D J Kontak, J A Petrus, P C Thurston
}

\section{To cite this version:}

Blandine Gourcerol, D J Kontak, J A Petrus, P C Thurston. Application of LA ICP-MS analysis of arsenopyrite to gold metallogeny of the Meguma Terrane, Nova Scotia, Canada. Gondwana Research, 2020, 81, pp.265-290. 10.1016/j.gr.2019.11.011 . hal-02442027

\section{HAL Id: hal-02442027 \\ https://hal.science/hal-02442027}

Submitted on 16 Jan 2020

HAL is a multi-disciplinary open access archive for the deposit and dissemination of scientific research documents, whether they are published or not. The documents may come from teaching and research institutions in France or abroad, or from public or private research centers.
L'archive ouverte pluridisciplinaire $\mathbf{H A L}$, est destinée au dépôt et à la diffusion de documents scientifiques de niveau recherche, publiés ou non, émanant des établissements d'enseignement et de recherche français ou étrangers, des laboratoires publics ou privés. 
archives-ouvertes

\section{Application of LA ICP-MS analysis of arsenopyrite to gold metallogeny of the Meguma Terrane, Nova Scotia, Canada}

Blandine Gourcerol, D Kontak, J Petrus, P Thurston

\section{To cite this version:}

Blandine Gourcerol, D Kontak, J Petrus, P Thurston. Application of LA ICP-MS analysis of arsenopyrite to gold metallogeny of the Meguma Terrane, Nova Scotia, Canada. Gondwana Research, Elsevier, 2020, 10.1016/j.gr.2019.11.011 . hal-02442027

\section{HAL Id: hal-02442027 \\ https://hal.archives-ouvertes.fr/hal-02442027}

Submitted on 16 Jan 2020

HAL is a multi-disciplinary open access archive for the deposit and dissemination of scientific research documents, whether they are published or not. The documents may come from teaching and research institutions in France or abroad, or from public or private research centers.
L'archive ouverte pluridisciplinaire HAL, est destinée au dépôt et à la diffusion de documents scientifiques de niveau recherche, publiés ou non, émanant des établissements d'enseignement et de recherche français ou étrangers, des laboratoires publics ou privés. 


\title{
Application of LA ICP-MS analysis of arsenopyrite to gold metallogeny of the Meguma Terrane, Nova Scotia, Canada
}

\author{
B. Gourcerol ${ }^{\mathrm{a}, \mathrm{b}, *}$, D.J. Kontak ${ }^{\text {a }}$, J.A. Petrus ${ }^{\text {a }}$, P.C. Thurston ${ }^{\mathrm{a}}$ \\ a Mineral Exploration Research Centre, Harquail School of Earth Sciences, Laurentian University, Sudbury, Ontario P3E 2C6, Canada \\ ${ }^{\mathrm{b}}$ Bureau de Recherches Géologiques et Minières (BRGM), Orléans, France
}

\section{A R T I C L E I N F O}

\section{Article history:}

Received 1 July 2019

Received in revised form 7 November 2019

Accepted 14 November 2019

Available online $\mathrm{xxx}$

Handling Editor: F. Pirajno

\section{Keywords:}

LA-ICP-MS

Metallogeny

Gold

Meguma Terrane

Orogenic deposit

\begin{abstract}
A B S T R A C T
Investigation of gold metallogeny in the Paleozoic Meguma terrane (Canada) is conducted through LA-ICP-MS analysis of arsenopyrite collected from eight slate-belt style vein gold deposits using a novel approach integrating elemental distribution maps and their derived elemental paragenesis with multi-element binary plots. The data reveal two distinct gold events: 1) an early event characterized by a Co-Ni-Mo-Sb-Se elemental association related to initial growth of arsenopyrite that reflects the presence of invisible gold $(>10 \mathrm{ppm})$; and 2) a second event, spatially associated with late fracture sets, that is characterized by an Al-Ti-V-Mn element association and reflects either remobilization or upgrading of primary invisible gold and is manifest as visible gold.

The results of this study indicate a complex and protracted history of gold mineralization which has important ramifications for the Meguma gold deposits, as well as other orogenic gold districts globally. In the case of the Meguma Terrane, it involves an initial gold event that is followed by element mobilization and, in the case of precious metals $(\mathrm{Au}, \mathrm{Ag})$, an upgrading through a zone refining process. In addition, the variable coupling and decoupling of elements is only revealed using in-situ derived LA-ICP-MS data.
\end{abstract}

\section{Introduction}

The Meguma Terrane of Nova Scotia (Canada) part of the larger Appalachian Orogen of eastern North America, hosts numerous orogenic gold deposits that equate to the slate-belt-hosted lode gold deposit type (e.g., Goldfarb et al., 1986; Poulsen et al., 2000; Bierlein and Crowe, 2000). These quartz-vein hosted deposits were exploited from the late 19th to the middle of the 20th century with a total recorded production of ca. 1.3 Moz Au from about 60 deposits (Sangster and Smith, 2007). More recent mining and exploration activity indicate, however, that the true endowment of these deposits is a multiple of this, as evidenced by the current and forecast production of $200,000 \mathrm{oz}$./year by Atlantic Gold Corp. from four of these historical deposit areas (http://www.atlanticgoldcorporation.com).

The nature of these deposits has been well documented by various studies which, in addition to regional- and deposit-scale studies, includes structural analysis, lithogeochemistry, geochronology, stable $(\mathrm{C}, \mathrm{O}, \mathrm{H})$ and radiogenic $(\mathrm{Sr}, \mathrm{Pb})$ isotopes, and fluid inclusions, as summarized by Ryan and Smith (1998) and Kontak and Horne (2010). The results of these studies indicate that similar overall geological settings, veins types, fluid chemistry and wall-rock alteration occurs in all the deposits, which strongly suggests a similar origin for gold mineralization across the entire terrane. However, despite having similar geological and geochemical features, at least two dis-

\footnotetext{
* Corresponding author at: Mineral Exploration Research Centre, Harquail School of Earth Sciences, Laurentian University, Sudbury, Ontario P3E 2C6, Canada. Email address: gourcerol.blandine@gmail.com (B. Gourcerol)
}

tinct vein-forming events are defined based on the aforementioned integrated studies: 1) an early event related to the regional Neoacadian orogenic deformation at ca. 410-390 Ma; and 2) a later event associated with the widespread emplacement of meta-to peraluminous granitoids and lesser mafic bodies at ca. 370-380 Ma. Importantly, gold mineralization in both cases has been attributed to the circulation of fluids carrying a metamorphic signature which coincide with regional deformation (ca. $408 \mathrm{Ma}$ ) and intrusion of large granitic batholiths (ca. $380 \mathrm{Ma}$ ) (Kontak and Horne, 2010; Kontak et al., 2011).Thus, despite the exhaustive amount of data available for these deposits (see further discussion below) there remain many outstanding questions about the elemental associations in these deposits, and the nature of both refractory and non-refractory gold in these systems. It is these aspects which are addressed in this paper.

A considerable advance in our understanding of the complex evolution and paragenesis of many gold deposit settings, such as multi-stage mineralizing events and/or remobilization, has been revealed through integration of classic petrographic and imaging methods (e.g., EMPA, SEM-EDS) with quantitative laser ablation inductively coupled plasma-mass spectrometry (LA-ICP-MS) element distribution analyses (i.e., maps, traverses, spots) of $\mathrm{Fe}-\mathrm{As}$ sulfide phases (e.g., Large et al., 2007, 2009; Zhoa et al., 2011; Lawley et al., 2015; Neyedley et al., 2017; Gourcerol et al., 2018a; Kerr et al., 2018; Dubosq et al., 2018; Wu et al., 2018, 2019). As a means to extract further information from such map and traverse data, Gourcerol et al. $(2018 \mathrm{a}, 2018 \mathrm{~b})$ introduced the novel concept of time slice domains (TSD) which essentially converts the LA traverse data used to construct maps into point analyses. When the latter approach is com- 


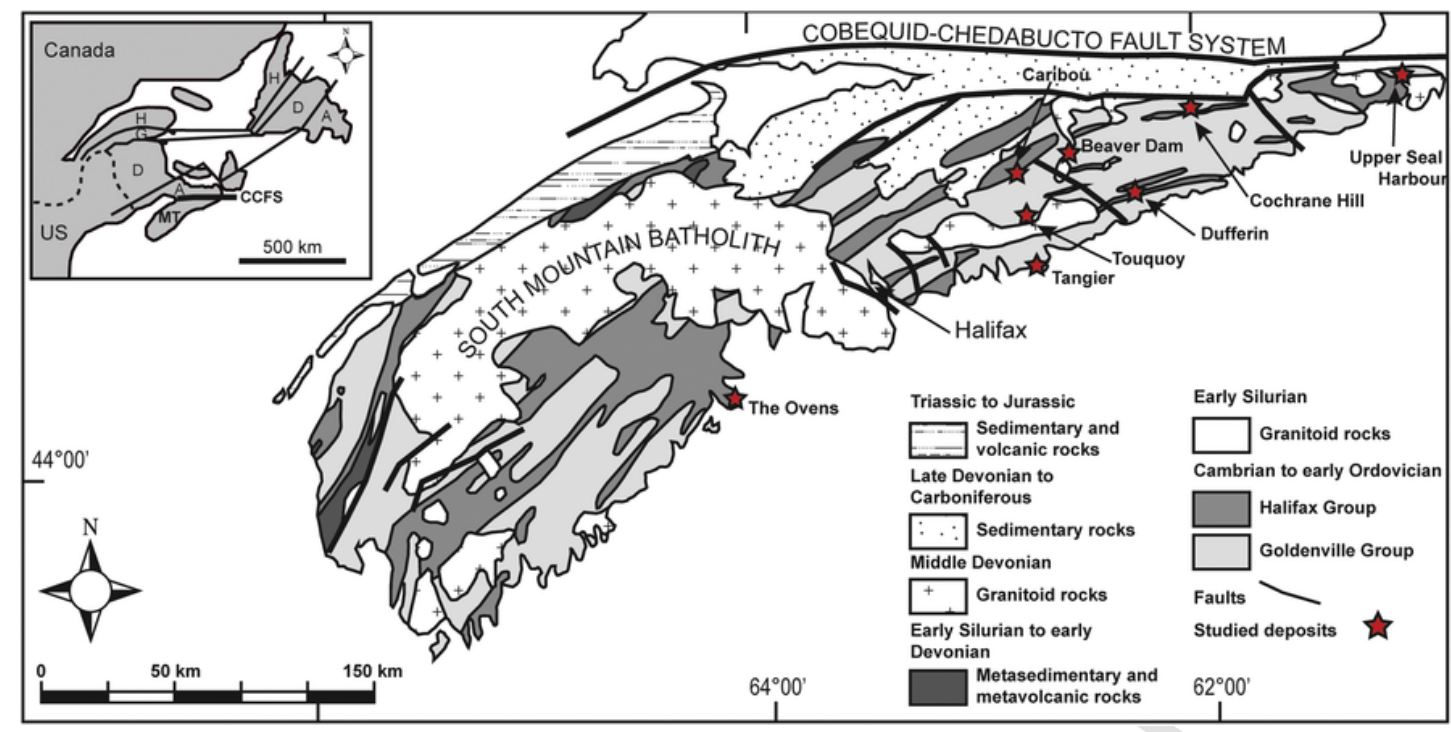

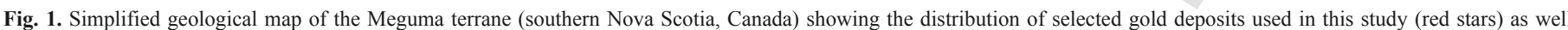

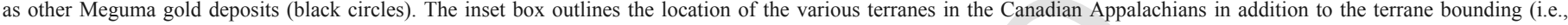

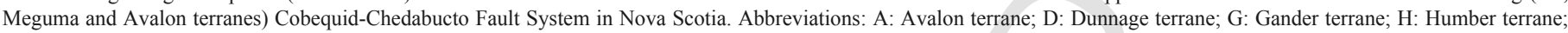
MT: Meguma terrane. (For interpretation of the references to color in this figure legend, the reader is referred to the web version of this article.)

bined with other concepts of data treatment, such as elemental paragenesis, multi-element plots and a variety of statistical approaches, it provides the means to assess the complexities of gold paragenesis, that is primary versus subsequent mobilization and upgrading or addition of new gold (e.g., Lawley et al., 2015; Augustin et al., 2017; Masurel et al., 2019). This latter approach has been successfully applied to better constrain the nature of gold (i.e., visible to invisible) in several deposit settings in Canada, including Archean BIF-hosted mineralization (e.g., the Meadowbank and Musselwhite deposits, the Meliadine gold district; Gourcerol, 2018a), the Archean orogenic Bisset Lake deposit, (Neyedley et al., 2017), the Archean intrusion-related Renabie deposit (McDivitt, 2016), and the hybrid orogenic-intrusion related Archean Madrid deposit, Hope Bay (Kerr et al., 2018).

In order to further assess the gold metallogeny of the Meguma terrane, that is the potential source(s) of gold and mineralizing fluid(s) plus the nature of the gold events, we present the results of LA-ICP-MS mapping of grains and traverses of arsenopyrite combined with treatment of these data using the TSD approach for several gold deposits (see Fig. 1). Our goal is to establish elemental associations and paragenesis for each deposit, assess the potential upgrading of $\mathrm{Au}$ within the sulfide host, constrain potential reservoirs with which the mineralizing fluids interacted, and assess the apparent similarity of many of these gold deposits. As this approach is both cost and time intensive, we acknowledge the dataset provided is albeit limited compared to more extensive lithogeochemical studies that are traditionally used, such as for the Meguma gold deposits themselves where Kerswill $(1988,1992)$ used 490 samples to show a strong correlation between both As and S versus Au. The advantage of our approach, as shown below and discussed by Gourcerol et al. (2018b), is that it provides a means to relate elements paragenetically versus spatially as in whole-rock analyses. Thus, this study is intended to be more of a proof of concept.

\section{Regional geological setting}

The Meguma terrane of southern Nova Scotia (Canada) defines the most easterly allochthonous part of the Canadian Appalachian orogenic belt (Fig. 1; Williams, 1995) with its emplacement coinci- dent with the Neoacadian Orogeny (van Staal, 2007; White and Barr, 2010). This terrane, around $480 \mathrm{~km}$ by $120 \mathrm{~km}$, consists of: 1) late Neoproterozoic (i.e., Ediacaran) to Ordovician metaturbiditic rocks (i.e., former Meguma Group), which includes the basal sandstone-dominant Goldenville Group (ca. $11 \mathrm{~km}$ ) and conformably overlying shale-dominant Halifax Group (ca. $5 \mathrm{~km}$ ) (White et al., 2012); 2) the disconformably overlying Silurian-Devonian metasedimentary and bimodal metavolcanic rocks of the Annapolis Supergroup (White et al., 2012); 3 ) voluminous ca. 380 to 370 Ma granitic batholiths (e.g., South Mountain Batholith) and smaller plutons with lesser gabbroic intrusions and mafic dike rocks (e.g., Kontak and Reynolds, 1994; Clarke et al., 1997; ); and 4) rare ca. $360 \mathrm{Ma}$ granitoid bodies restricted to the southwest Meguma terrane (see Kontak et al. (2013) for summary) (Table 1). The metasedimentary and metavolcanic units were intensely deformed and metamorphosed (i.e., greenschist-amphibolite facies) in the Late Devonian (e.g., Kontak et al., 1998; Hicks et al., 1999) during the collision of the Meguma and Avalon terranes (ca. 410-390 Ma) along the east-west trending Cobequid-Chedabucto Fault System (CCFZ; Fig. 1; Murphy et al., 2012). The overlying clastic rocks of the Late Devonian-Early Carboniferous Horton Group, which on-lap the CCFZ, record the uplift and erosion of the aforementioned deformed rocks.

The basement of the Meguma terrane (i.e., substrate to the Meguma metasedimentary rocks) is not well documented and remains equivocal. At the supracrustal level, some workers (Clarke et al., 1993; Dostal et al., 2006) interpret the intensely folded, high-grade rocks represented by ortho- and paragneisses exposed in the so-called Liscomb Complex to be analogous to a gneiss dome, whereas others (White et al., 2009; Scallion et al., 2011) consider these rocks to be part of a contact metamorphic aureole related to proximal granites. The presence, however, of granulite facies xenoliths in ca. $374 \mathrm{Ma}$ lamprophyric dyke rocks of the eastern Meguma terrane (Owen et al., 1988; Ebertz et al., 1991; Greenough et al., 1999) and as fragments in megabreccias in the CCFZ (Gibbons et al., 1996) indicate the unequivocal presence of a high-grade basement infrastructure. The aforementioned lamprophyre-hosted xenoliths, termed the Tangier xenoliths, include sapphirine granulites, mafic gneisses 
Table 1

Summary of the major events and their respective ages affecting the Meguma and Avalon terranes (Nova Scotia, Canada).

\begin{tabular}{|c|c|c|c|c|}
\hline Events & Age & Methods & Comments & References \\
\hline $\begin{array}{l}\text { Ordovician } \\
\text { granitic and } \\
\text { gabbroic } \\
\text { magmatism }\end{array}$ & $460 \mathrm{Ma}$ & $\mathrm{U} / \mathrm{Pb}(\mathrm{zr})$ & $\begin{array}{l}\text { Located in the } \\
\text { Avalon terrane, } \\
\text { refers to A-type } \\
\text { granites }\end{array}$ & $\begin{array}{l}\text { Escarraga } \\
\text { et al., } \\
2012 \text {; } \\
\text { Murphy et } \\
\text { al., } 2012\end{array}$ \\
\hline $\begin{array}{l}\text { Early Silurian } \\
\text { igneous } \\
\text { activity }\end{array}$ & $440 \mathrm{Ma}$ & $\mathrm{U} / \mathrm{Pb}(\mathrm{zr})$ & $\begin{array}{l}\text { Reported in the } \\
\text { western part of } \\
\text { the Meguma } \\
\text { terrane, from } \\
\text { volcanic rocks } \\
\text { within the White } \\
\text { Rock Formation } \\
\text { and the Brenton } \\
\text { pluton }\end{array}$ & $\begin{array}{l}\text { Keppie and } \\
\text { Krogh, } \\
2000 ; \\
\text { MacDonald } \\
\text { et al., } 2002\end{array}$ \\
\hline $\begin{array}{l}\text { Acadian } \\
\text { orogeny }\end{array}$ & $410-390 \mathrm{Ma}$ & $\begin{array}{l}{ }^{40} \mathrm{Ar} /{ }^{39} \mathrm{Ar} \\
\text { (wr) }\end{array}$ & $\begin{array}{l}\text { Corresponds to } \\
\text { regional } \\
\text { metamorphism } \\
\text { and deformation }\end{array}$ & $\begin{array}{l}\text { Keppie and } \\
\text { Dallmeyer, } \\
\text { 1987; } \\
\text { Muecke et } \\
\text { al., 1988; } \\
\text { Kontak et } \\
\text { al., 1998, } \\
\text { 2002; } \\
\text { Hicks et } \\
\text { al., } 1999\end{array}$ \\
\hline $\begin{array}{l}\text { Peraluminous } \\
\text { granitoid } \\
\text { emplacement }\end{array}$ & $370-380 \mathrm{Ma}$ & $\begin{array}{l}{ }^{40} \mathrm{Ar} /{ }^{39} \mathrm{Ar} \\
(\mathrm{ms}, \mathrm{bt}) \\
\mathrm{U} / \mathrm{Pb}(\mathrm{zr}, \\
\mathrm{mz})\end{array}$ & $\begin{array}{l}\text { Described as S- } \\
\text { type granites; U/ } \\
\text { Pb reflects age of } \\
\text { crystallization; } \\
\text { Ar/Ar reflects } \\
\text { cooling of } \\
\text { plutons; }\end{array}$ & $\begin{array}{l}\text { Hill, 1988; } \\
\text { Reynolds } \\
\text { et al., } \\
\text { 1981; } \\
\text { Bradley, } \\
\text { 1983; } \\
\text { Keppie and } \\
\text { Dallmeyer, } \\
\text { 1987, } \\
\text { 1995; } \\
\text { Krogh and } \\
\text { Keppie, } \\
\text { 1988; } \\
\text { Clarke et } \\
\text { al., 1993; } \\
\text { Keppie et } \\
\text { al., 1993; } \\
\text { Kontak et } \\
\text { al., 2004; } \\
\text { Kontak and } \\
\text { Reynolds, } \\
\text { 1994; Tate } \\
\text { et al., } \\
\text { 1997; } \\
\text { Keppie and } \\
\text { Krogh, } \\
\text { 1999; } \\
\text { Murphy } \\
\text { and } \\
\text { Keppie, } \\
\text { 2005; } \\
\text { Chen, 2015 }\end{array}$ \\
\hline $\begin{array}{l}\text { Emplacement } \\
\text { of gneisses of } \\
\text { the Liscomb } \\
\text { Complex }\end{array}$ & $374-377 \mathrm{Ma}$ & $\begin{array}{l}{ }^{40} \mathrm{Ar} /{ }^{39} \mathrm{Ar} \\
(\mathrm{wr}) \mathrm{U} / \\
\mathrm{Pb}(\mathrm{zr}, \\
\mathrm{mz})\end{array}$ & $\begin{array}{l}\text { Contemporaneous } \\
\text { with } \\
\text { peraluminous } \\
\text { granites, closely } \\
\text { associated with } \\
\text { amphibolite- } \\
\text { granulite facies } \\
\text { metamorphism }\end{array}$ & $\begin{array}{l}\text { Kontak and } \\
\text { Reynolds, } \\
\text { 1994; } \\
\text { Dostal et } \\
\text { al., } 2006\end{array}$ \\
\hline $\begin{array}{l}\text { Emplacement } \\
\text { of mafic } \\
\text { intrusions } \\
\text { and dikes }\end{array}$ & $370-374 \mathrm{Ma}$ & $\begin{array}{l}{ }^{40} \mathrm{Ar} /{ }^{39} \mathrm{Ar} \\
(\mathrm{hbl}, \mathrm{bt})\end{array}$ & $\begin{array}{l}\text { Dating performed } \\
\text { on hbl and bt; } \\
\text { Rapid cooling of } \\
\text { dikes and } \\
\text { gabbroic bodies } \\
\text { (e.g., Liscomb } \\
\text { area) }\end{array}$ & $\begin{array}{l}\text { Kempster } \\
\text { et al., } \\
1989 ; \\
\text { Kontak and } \\
\text { Reynolds, } \\
1994\end{array}$ \\
\hline $\begin{array}{l}\text { Granitic } \\
\text { magmatism }\end{array}$ & $360 \mathrm{Ma}$ & $\begin{array}{l}{ }^{40} \mathrm{Ar} /{ }^{39} \mathrm{Ar} \\
(\mathrm{ms}) \mathrm{Re} / \\
\mathrm{Os}(\mathrm{mb})\end{array}$ & $\begin{array}{l}\text { Described as A- } \\
\text { and I-type } \\
\text { granites; } \\
\text { Reported in the } \\
\text { Southwestern part } \\
\text { of the Meguma } \\
\text { deposit }\end{array}$ & $\begin{array}{l}\text { Kontak et } \\
\text { al., } 2013\end{array}$ \\
\hline
\end{tabular}

and garnetiferous quartzo-feldspathic gneisses (Owen et al., 1988; Owen and Greenough, 1991).

\subsection{Geological and geochemical parameters of Meguma gold deposits}

The Meguma lode-gold deposits discussed below are present throughout the metasandstone dominant Goldenville Group with a few also at the base of the overlying, mudstone dominant Halifax Group (Malcolm, 1929; Ryan and Smith, 1998; Horne and Culshaw, 2001). The deposits are well constrained in terms of their structural settings, as it has long been known that they are localized in the hinge areas of anticlines or their southern, often overturned limbs (Malcolm, 1929; Keppie, 1976; Horne and Culshaw, 2001). The deposits consist of a variety of quartz vein types, including bedding concordant, discordant, en echelon, and saddle reef (Malcolm, 1929; Keppie, 1976: Graves and Zentilli, 1982; Horne and Culshaw, 2001; Kontak and Horne, 2010). Despite their various geometrical relationships to their host rocks, most of these veins are now considered to represent emplacement during a late-stage fold tightening and, based on their mutual cross-cutting relationships, to represent in a specific deposit a single vein-forming event (Horne and Culshaw, 2001; Kontak and Horne, 2010). It has also been shown that individual deposits may be dominated by one vein type, thus, for instance, saddle veins at The Ovens, Upper Seal Harbour, and Dufferin deposits, whereas bedding-concordant veins at Beaver Dam, Cochrane Hill, and Moose River deposits, and both discordant and concordant vein types at Caribou and Tangier deposits. These latter named settings representing the focus of this study (Fig. 1).

The auriferous veins are generally dominated by a simple quartz \pm carbonate \pm sulfide mineral assemblage (Malcolm, 1929; Newhouse, 1936; Kontak and Horne, 2010), hence similar to most orogenic vein systems (Goldfarb et al., 2005; Dubé and Gosselin, 2007), and often have ribbon textures due to inclusion of thin wall-rock slivers or septae. The sulfides include arsenopyrite, which is locally the dominant sulfide phase, in addition to pyrite, pyrrhotite, galena, sphalerite and chalcopyrite. Gold is present in all the vein types mentioned and occurs in a variety of settings (e.g., Kontak and Smith 1993; Kontak et al., 1996; Ryan and Smith, 1998), which includes discrete grains in vein quartz, along wall-rock contacts or adhering to ribbons of wall-rock, attached to sulfides (arsenopyrite \pm galena \pm pyrrhotite \pm pyrite \pm sphalerite), or as fracture-filling/inclusions within sulfides, in particular arsenopyrite. Although low-grade (i.e., $<1-2 \mathrm{~g} / \mathrm{t} \mathrm{Au}$ ) disseminated-type (i.e., vein-poor packages) gold mineralization is present in the metasedimentary host rocks, it has only been recognized as a significant component of the mineralization in a few settings (e.g., Touquoy, Fifteen Mile Stream, Beaver Dam), with the Touquoy deposit of the Moose River district the only site where this has been studied in detail (Bierlein and Smith, 2003). In the latter case, a global resource of a 550,000 oz. @ 1.55 g/t was indicated prior to commencement of mining in 2018 (http://www.atlanticgoldcorporation. com/projects/tourquay_gold_project). As in other metasedimentary rock-hosted gold settings (Bierlein and Crowe, 2000), wall-rock alteration varies from cryptic to intensely developed with zones of sericite, silica, carbonate (e.g., ankerite and calcite), and Fe-sulfides (i.e., arsenopyrite) the most abundant; in addition are rare biotite and tourmaline alteration (e.g., Kontak and Smith, 1989, 1993; Bierlein and Smith, 2003; Kontak and Horne, 2010).

Given the similar settings, vein paragenesis, and fluid chemistry, as constrained by isotopes ( $, \mathrm{O}, \mathrm{D}, \mathrm{C})$, fluid inclusions (i.e., aqueous carbonic, $\mathrm{X}_{\mathrm{CO} 2}=0.10-0.2,5-10 \mathrm{wt} \%$ equiv. $\mathrm{NaCl}$ ), and wall-rock al- 
Table 2

Summary of the relevant geology of the studied gold deposits from the Meguma terrane (Nova Scotia, Canada).

\begin{tabular}{|c|c|c|c|c|c|c|c|}
\hline Deposits & Localization & Stratigraphy & $\begin{array}{l}\text { Deposit- } \\
\text { type }\end{array}$ & Metamorphism & Dating & Comments & References \\
\hline $\begin{array}{r}\text { Beaver } \\
\text { Dam }\end{array}$ & $\begin{array}{l}\text { Southern limb of the Beaver } \\
\text { Dam northeast-trending } \\
\text { anticline; close to River Lake } \\
\text { granite intrusion }\end{array}$ & $\begin{array}{l}\text { Metasiltstones } \\
\text { (Goldenville } \\
\text { Formation) }\end{array}$ & $\begin{array}{l}\text { Bedding- } \\
\text { parallel and } \\
\text { discordant } \\
\text { narrow qtz } \\
\text { veins }\end{array}$ & Greenschist & $\begin{array}{l}460 \mathrm{Ma}(\mathrm{Re} / \\
\mathrm{Os}), 440 \mathrm{Ma} \\
(\mathrm{Re} / \mathrm{Os}), \\
370-380 \mathrm{Ma} \\
(\mathrm{Ar} / \mathrm{Ar})\end{array}$ & $\begin{array}{l}{ }^{40} \mathrm{Ar} /{ }^{39} \mathrm{Ar} \text { performed on } \\
\text { vein-fill minerals (hbl, } \\
\mathrm{ms} \text {, bt) and whole rock; } \\
\mathrm{Re} / \text { Os performed on } \\
\text { Aspy }\end{array}$ & $\begin{array}{l}\text { Kontak et al., 1990b, } \\
\text { 1993; Kontak and } \\
\text { Smith, 1993; Kontak } \\
\text { and Kerrich, 1995; } \\
\text { Chen, } 2015\end{array}$ \\
\hline The Ovens & Hinge of the Ovens Anticline & $\begin{array}{l}\text { Metasiltstones } \\
\text { (Goldenville } \\
\text { Formation) }\end{array}$ & $\begin{array}{l}\text { Saddle-reef } \\
\text { concordant } \\
\text { and } \\
\text { discordant } \\
\text { qtz veins }\end{array}$ & Greenschist & $\begin{array}{l}406 \mathrm{Ma}(\mathrm{Re} / \\
\mathrm{Os}), 380 \mathrm{Ma} \\
\text { (Re/Os; } \mathrm{Ar} / \\
\mathrm{Ar})\end{array}$ & $\begin{array}{l}{ }^{40} \mathrm{Ar} /{ }^{39} \mathrm{Ar} \text { performed on } \\
\text { ms from pressure } \\
\text { shadows around Aspy } \\
\text { and bt alteration; Re/Os } \\
\text { performed on Aspy }\end{array}$ & $\begin{array}{l}\text { Hicks et al., 1999; } \\
\text { Kontak et al., 1998; } \\
\text { Kontak; Horne and } \\
\text { Culshaw, 2001; Morelli } \\
\text { et al., 2005; Chen, } 2015\end{array}$ \\
\hline Dufferin & $\begin{array}{l}\text { Hinge of the Crown Reserve } \\
\text { Anticline }\end{array}$ & $\begin{array}{l}\text { Metasiltstones } \\
\text { (Goldenville } \\
\text { Formation) }\end{array}$ & $\begin{array}{l}\text { Saddle-reef } \\
\text { concordant } \\
\text { qtz veins }\end{array}$ & Greenschist & $\begin{array}{l}408 \mathrm{Ma}(\mathrm{Ar} / \\
\mathrm{Ar}), 380 \mathrm{Ma} \\
(\mathrm{Re} / \mathrm{Os})\end{array}$ & $\begin{array}{l}{ }^{40} \mathrm{Ar} /{ }^{39} \mathrm{Ar} \text { performed on } \\
\text { wall rock adjacent to } \\
\text { discordant vein; Re/Os } \\
\text { performed on Aspy }\end{array}$ & $\begin{array}{l}\text { Morelli et al., 2005; } \\
\text { Horne and Culshaw, } \\
\text { 2001; Kontak et al., } \\
\text { 1998; }\end{array}$ \\
\hline Touquoy & $\begin{array}{l}\text { Centred on the Moose River } \\
\text { Anticline }\end{array}$ & $\begin{array}{l}\text { Metasiltstones } \\
\text { (Goldenville } \\
\text { Formation) }\end{array}$ & $\begin{array}{l}\text { Bedding- } \\
\text { parallel and } \\
\text { discordant } \\
\text { narrow qtz } \\
\text { veins }\end{array}$ & Greenschist & $\begin{array}{l}440 \mathrm{Ma}(\mathrm{Re} / \\
\mathrm{Os}), \\
410-400 \mathrm{Ma} \\
(\mathrm{Ar} / \mathrm{Ar} ; \mathrm{Re} / \\
\mathrm{Os}), 380 \mathrm{Ma} \\
(\mathrm{Ar} / \mathrm{Ar})\end{array}$ & $\begin{array}{l}{ }^{40} \mathrm{Ar}{ }^{39} \mathrm{Ar} \text { performed on } \\
\text { vein-micas and whole } \\
\text { rock }\end{array}$ & $\begin{array}{l}\text { Kontak et al., 1990b, } \\
\text { 1993; Bierlein and } \\
\text { Smith, 2003; Chen, } \\
2015\end{array}$ \\
\hline $\begin{array}{l}\text { Cochrane } \\
\text { Hill }\end{array}$ & $\begin{array}{l}\text { Eastward extension of the } \\
\text { Cochrane Hill Anticline }\end{array}$ & $\begin{array}{l}\text { Metasiltstones } \\
\text { (Goldenville } \\
\text { Formation) }\end{array}$ & $\begin{array}{l}\text { Bedding- } \\
\text { parallel }\end{array}$ & Amphiolite & & & $\begin{array}{l}\text { Smith, 1983a, b; Smith, } \\
1984\end{array}$ \\
\hline Caribou & $\begin{array}{l}\text { Northest-trending Caribou } \\
\text { Anticline }\end{array}$ & $\begin{array}{l}\text { Metasiltstones } \\
\text { (Goldenville } \\
\text { Formation) }\end{array}$ & $\begin{array}{l}\text { Bedding- } \\
\text { parallel and } \\
\text { discordant } \\
\text { narrow qtz } \\
\text { veins }\end{array}$ & Greenschist & $\begin{array}{l}373 \mathrm{Ma}(\mathrm{Ar} / \\
\mathrm{Ar})\end{array}$ & $\begin{array}{l}{ }_{\mathrm{ms}}^{40} \mathrm{Ar} \\
{ }^{39} \mathrm{Ar} \text { performed on }\end{array}$ & Kontak et al., 1990b \\
\hline $\begin{array}{l}\text { Upper Seal } \\
\text { Harbour }\end{array}$ & Hinge of an anticlinal & $\begin{array}{l}\text { Metasiltstones } \\
\text { (Goldenville } \\
\text { Formation) }\end{array}$ & $\begin{array}{l}\text { Saddle-reef } \\
\text { concordant } \\
\text { veins }\end{array}$ & Greenschist & $\begin{array}{l}366 \mathrm{Ma}(\mathrm{Ar} / \\
\mathrm{Ar})\end{array}$ & $\begin{array}{l}{ }_{\mathrm{ms}}^{40} \mathrm{Ar}{ }^{39} \mathrm{Ar} \text { performed on } \\
\end{array}$ & Kontak et al., 1990b \\
\hline Tangier & $\begin{array}{l}\text { Southern limb of the Tangier- } \\
\text { Harrigan Cove northeast- } \\
\text { trending anticline; close to the } \\
\text { Musquodobit batholith }\end{array}$ & $\begin{array}{l}\text { Metasiltstones } \\
\text { (Goldenville } \\
\text { Formation) }\end{array}$ & $\begin{array}{l}\text { Bedding } \\
\text { concordant } \\
\text { and } \\
\text { discordant }\end{array}$ & Greenschist & $\begin{array}{l}374 \mathrm{Ma}(\mathrm{Ar} / \\
\mathrm{Ar})\end{array}$ & $\begin{array}{l}{ }_{\mathrm{bt}}^{40} \mathrm{Ar} \\
{ }^{39} \mathrm{Ar} \text { performed on }\end{array}$ & $\begin{array}{l}\text { Corey and Mills, 1992; } \\
\text { Smith, 2000; Kontak } \\
\text { and Archibald, } 2002\end{array}$ \\
\hline
\end{tabular}

Abbreviations: Aspy=arsenopryite; $\mathrm{bt}=$ biotite, $\mathrm{hbl}=$ hornblende, $\mathrm{ms}=$ muscovite.

teration, these deposits have been suggested to share a metamorphic origin (e.g., Graves and Zentilli, 1982; Kontak et al., 1990a, 2011; Kontak and Kerrich, 1997; Ryan and Smith, 1998; Kontak and Horne, 2010). However, direct dating ( $\left.\mathrm{Re}-\mathrm{Os},{ }^{40} \mathrm{Ar} /{ }^{39} \mathrm{Ar}\right)$ of some deposits indicate at least two distinct gold mineralizing events (see summary in Table 2): 1) an early one, coincident with regional deformation and recognized locally at Beaver Dam, The Ovens, and Touquoy deposits based on Re/Os dating of arsenopyrite grains (e.g., Morelli et al., 2005; Chen et al., 2014; Chen, 2015); and 2) a later event, which overlaps the felsic(-mafic) magmatism at ca. $380-370 \mathrm{Ma}$, as constrained by ${ }^{40} \mathrm{Ar} /{ }^{39} \mathrm{Ar}$ (whole rock, amphibole, muscovite, biotite; see summary in Kontak and Archibald (2002) andKontak and Horne (2010) and Re -Os on arsenopyrite grains (Morelli et al., 2005) dating. This gold event is represented at Beaver Dam, The Ovens, Dufferin, Touquoy, Upper Seal Harbour, Tangier and Caribou deposits. Thus, there is some evidence for possibly multiple hydrothermal events in these deposits (e.g., Beaver Dam), the degree and significance of which remains unquantified, as has also been recorded in other orogenic gold deposit settings (e.g., Wagner et al., 2007; Lawley et al., 2015; Kerr et al., 2018).

\subsection{Occurrence of arsenopyrite}

As noted above, arsenopyrite is a common sulfide phase in the Meguma deposits in both mineralized and barren veins and in adja- cent wall rock. Representative examples from among the various deposit sites are shown in Fig. 2 (see Fig. 1 for locations) and includes Beaver Dam (Fig. 2A, B, C, D), Touqouy (Fig. 2E, F, G), The Ovens (Fig. 2H, I, J), Dufferin (Fig. 2K), Mooseland (Fig. 2L, M, N), and Fifteen Mile Stream (Fig. 2O). In general, arsenopyrite is seen to occur as: 1) layers partially to wholly replacing wall rock where it is concentrated as thin layers along bedding-plane horizons (Fig. 2A, B, $\mathrm{C}, \mathrm{N}, \mathrm{O}$ ) or replacing beds (Fig. 2I, J); 2) disseminations in the various metasedimentary host rocks (Fig. 2F); 3) coarse porphyroblasts in the host rocks (Fig. 2C, D, E, G); 4) coarse euhedral in quartz-dominant veins (Fig. 2H, M, L) or the dominant phase of small quartz veins (Fig. 2E); and 5) replacing wall-rock ribbons having stylolitic texture, as seen in a mineralized quartz vein (Fig. $2 \mathrm{~K}$ ).

The timing of arsenopyrite in relation to vein formation is poorly constrained, in particular when present as disseminations (Fig. 2F), porphyroblasts (Fig. 2C, G), or replacing beds (Fig. 2J). However, where fabric development is observed, the formation of pressure shadows (Fig. 2E) or boudinaging of veins (Fig. 2H) about arsenopyrite indicates at least some of these grains are pre- to syndeformation. Given that the emplacement of the majority of the quartz veins have been considered to reflect a late-stage folding tightening event of the Meguma stratigraphy (Horne and Culshaw, 2001), it follows therefore that the timing of arsenopyrite growth would also be considered to be synchronous with vein formation (i.e., fluid flux). 

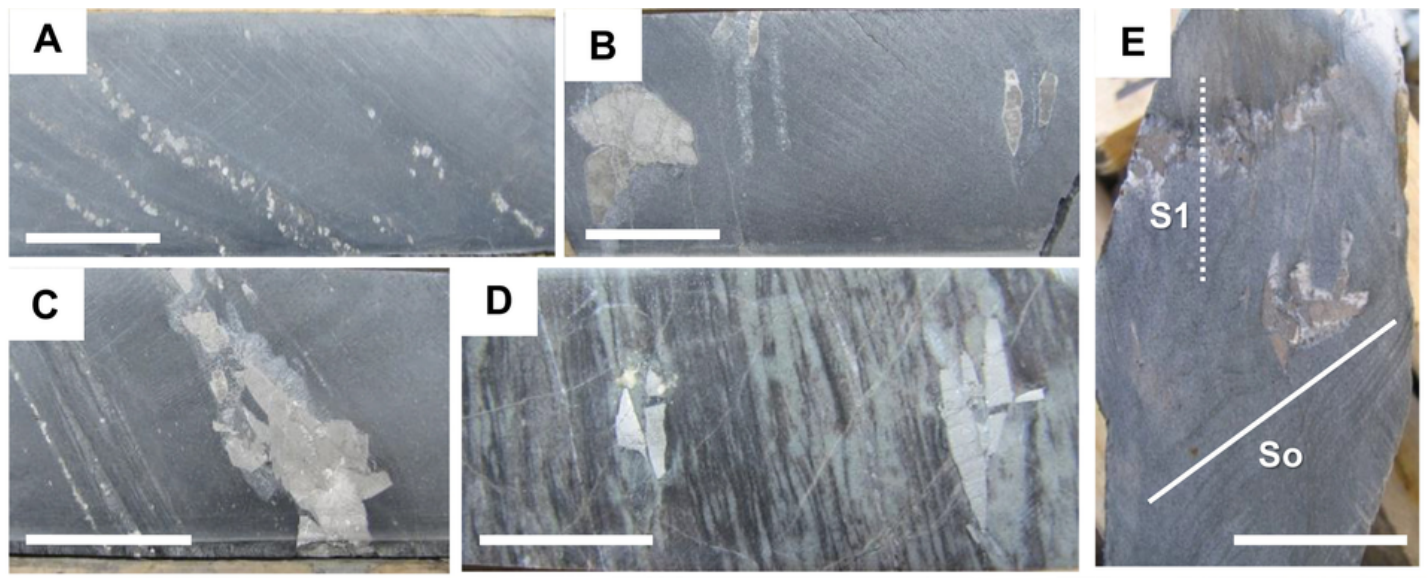

D
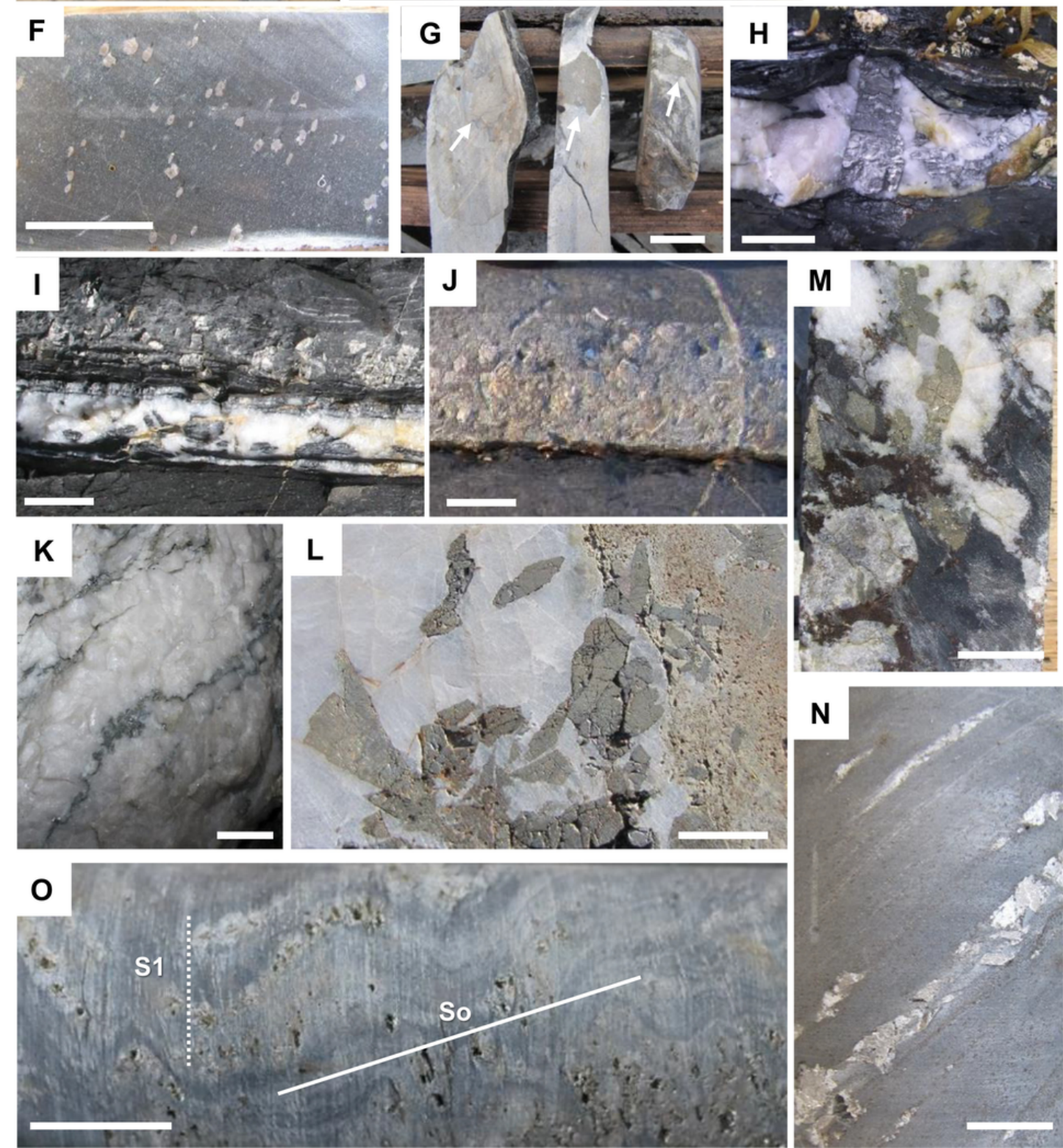

Fig. 2. Representative images of outcrop (H, I, J, K) and drill core (all others) showing the style of arsenopyrite (Aspy) found in the Meguma gold deposits with samples from the following locations (see Fig. 1). Note that the white line on each picture represents $2 \mathrm{~cm}$. A, B, C, D) Beaver Dam; E, F, G) Touquoy; H, I, J) The Ovens; K) Dufferin; L, M, N) Mooseland; O) Fifteen Mile Stream. A) Aspy along bedding-plane horizons and lacking quartz. B, C) Coarse porphyroblastic aspy, in part as aggregates (see image C) lacking pres- 


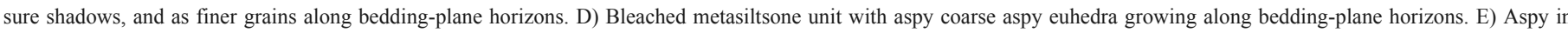

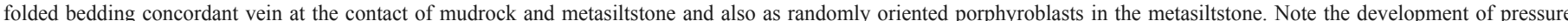

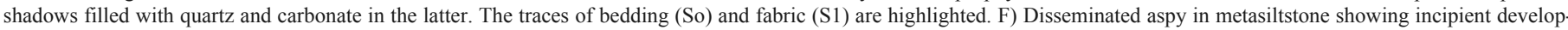

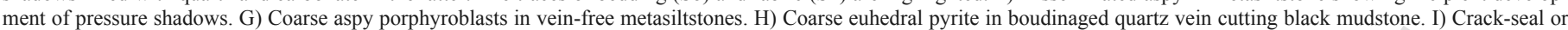

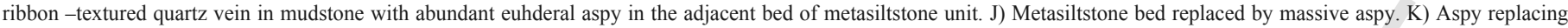

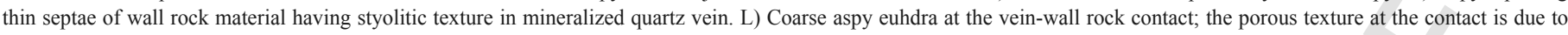

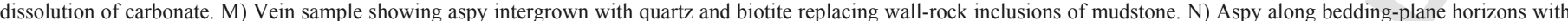

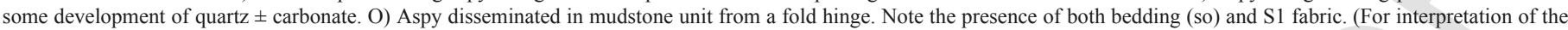
references to color in this figure legend, the reader is referred to the web version of this article.)

Table 3

LA-ICP-MS Instrumentation and acquisition parameters.

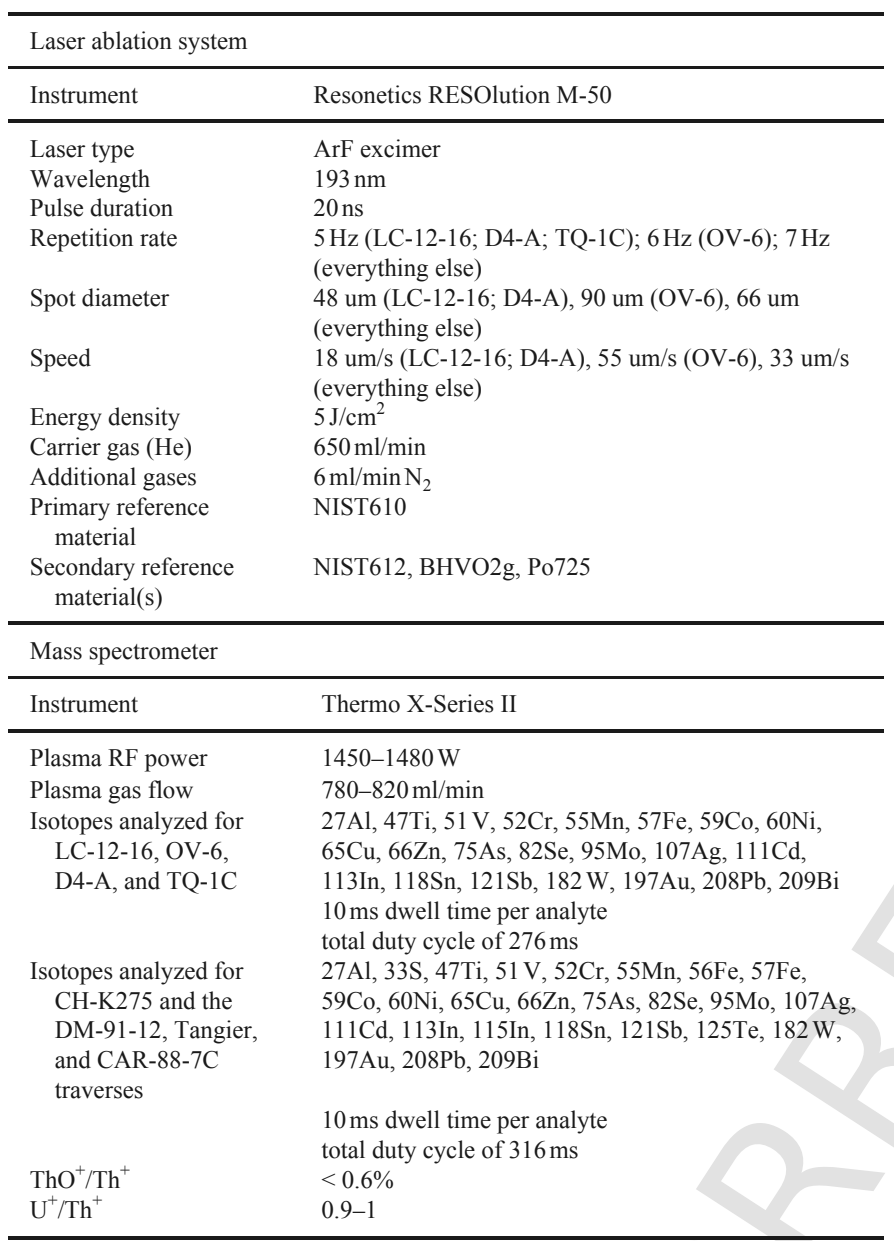

$\mathrm{ThO}^{+} / \mathrm{Th}^{+}$and $\mathrm{U}^{+} / \mathrm{Th}^{+}$were determined on NIST612 during instrument tuning. and approximately $2.5 \mathrm{~m}$ before entering the torch. The combined aerosol was fed into a Thermo X-Series II quadrupole ICP-MS for elemental analysis. The analyses consisted of traverses and maps (themselves consisting of a series of adjacent, equal length traverses) that were acquired by moving the sample under the laser at speeds of $1 / 3$ to $1 / 2$ the spot diameter per second. Between each traverse, 30 to $45 \mathrm{~s}$ of gas blank was collected to be used for baseline subtraction during data reduction. Reference materials (a combination of NIST610 +/NIST612, BHVO2g and Po725) were analyzed periodically to account for instrument drift. The data were collected in several sessions from 2014 to 2016, with each map taking 4 to $7 \mathrm{~h}$ to acquire. The laser and ICP-MS operating conditions are listed in Table 3.

The raw data were quantified using the trace-element data reduction scheme of Iolite 3 (Paton et al., 2011), where NIST610 (Jochum et al., 2011) and Fe acted as the external and internal references for quantification, respectively. A slight modification was made to the trace element data reduction scheme so that the Fe was not forced to $34.3 \%$ on a point-by-point or a pixel-by-pixel basis, but to the mean of a representative and clean part of the arsenopyrite grain. This was done to avoid over or under estimating concentrations in fractures and inclusions where the Fe and ablation rate can vary. In fractures and inclusions, the data are considered to be semi-quantitative. Although the arsenopyrites and reference materials used differ significantly in terms of their chemistry and ablation efficiency, Wohlgemuth-Ueberwasser and Jochum (2015) and Gourcerol et al. (2018b) have shown that using the NIST610/Fe calibration strategy to quantify PGEs in a sulfide $(\mathrm{Po})$ yields concentrations acceptably close to what is expected. Additional experiments conducted as part of this study demonstrate that a wide range of elements in Fe-rich reference materials including GSD-1G, GSE-1G, BHVO2G and MASS1 (USGS), and Po725 (Sylvester et al., 2005) are mostly within 20\% of their accepted values when calibrated this way (cf., Fig. A). A homogeneous, well characterized reference arsenopyrite does not exist that we are aware of, therefore this combined evidence of a wide range of Fe-rich materials being acceptably calibrated with NIST610/Fe provides reasonable confidence in the arsenopyrite concentrations determined this way. It is also noteworthy that the type of data analysis performed here (TSD-based) is concerned more with orders of magnitude concentration variations rather than subtle differences, thus rendering minor inaccuracies irrelevant.

Element maps were stitched together using Iolite's "Image from Selections" functionality (Woodhead et al., 2007), with additional bilinear interpolation between traverses and $3 \times 3$ mean pixel smoothing. This was done for the images (i.e., Figs. 3-7), but not for the TSD (i.e., Figs. 14-18), for which no interpolation or smoothing were performed in order to avoid biasing the data.

The analyses were performed on euhedral arsenopyrite grains with element distribution maps acquired for samples from the Beaver Dam, The Ovens, Dufferin, Touquoy and Cochrane Hill deposits, whereas element distribution traverses were acquired for samples from the Upper Seal Harbour, Tangier and Caribou deposits. Arsenopyrite grains were sampled from bedding parallel quartz veins, except for The Ovens, which were hosted in metasiltstone adjacent to a bedding parallel vein. The samples used for LA-ICP-MS analysis were are examined in both reflected light and also using the scan- in ultra-pure He flowing at $650 \mathrm{ml} / \mathrm{min}$. The ablated material and $\mathrm{He}$ were combined with $\mathrm{Ar}(780-820 \mathrm{ml} / \mathrm{min})$ and a small flow of $\mathrm{N}_{2}$ $(6 \mathrm{ml} / \mathrm{min}$; to enhance sensitivity, Hu et al., 2008) just outside the cell maps referred to below. The selected areas were ablated with a Resonetics RESOlution M-50, $193 \mathrm{~nm}$ wavelength, $20 \mathrm{~ns}$ pulse duration ArF excimer laser ablation microprobe employing a Laurin Technic two-volume sample cell (Müller et al., 2009). Ablation took place 

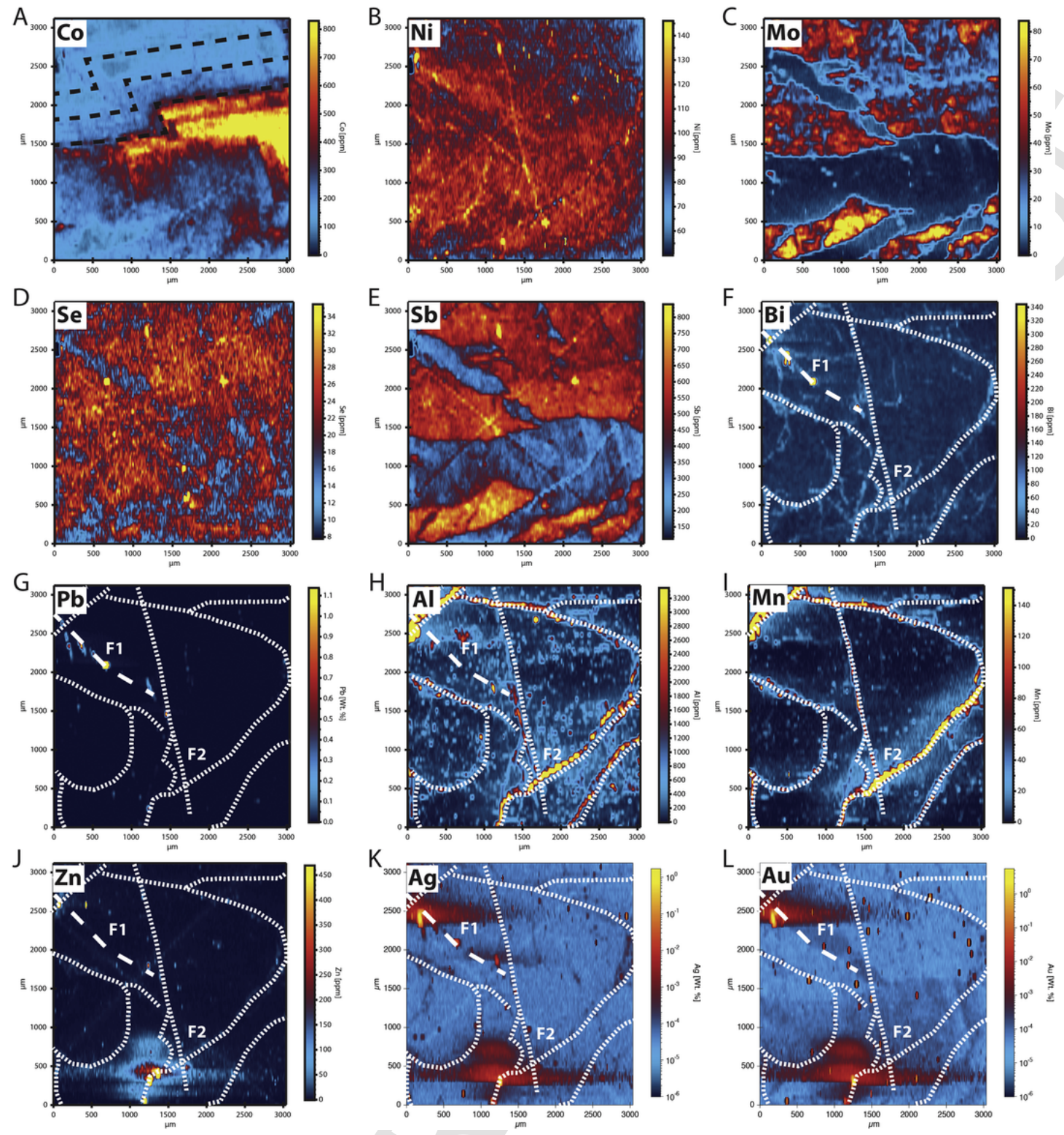

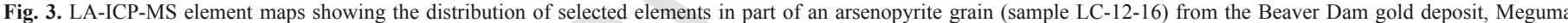

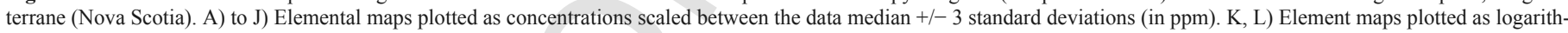

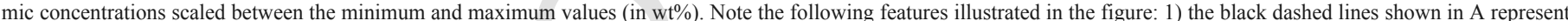

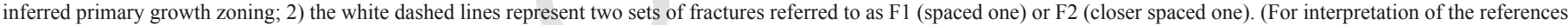
to color in this figure legend, the reader is referred to the web version of this article.)

ning electron microscopy coupled with an energy dispersive X-ray spectrometry (SEM-EDS).

\section{Results and interpretation}

\subsection{Elemental paragenesis}

Quantitative LA-ICP-MS element distribution maps and traverses (Table 4) were performed on several arsenopyrite grains from eight different deposits from the central and eastern part of the Meguma terrane (Fig. 1): Beaver Dam (Fig. 3), The Ovens (Fig. 4), Dufferin (Fig. 5), Touquoy (Fig. 6), Cochrane Hill (Fig. 7), Upper Seal Harbour (Fig. 8), Tangier (Fig. 9), and Caribou (Figs. 10, 11). These analyses, in combination with detailed petrographic and/or SEM-
EDS study, provide the basis for establishing an elemental paragenesis for each deposit, which is shown in Fig. 12 and discussed in detail below. This procedure is paramount in determining elemental associations for each of the deposits and is the first step towards understanding the mineralizing event in a deposit. In regards to the paragenesis presented, we note that not all the elements summarized in Fig. 12 are shown in the elemental distribution maps presented.

We first note in regards to the elemental maps and related elemental paragenesis, that despite being located in different stratigraphic settings with respect to both potential facies variation and host-rock relative age in the Meguma stratigraphy, the studied samples and hence deposits reveal a very similar elemental paragenesis. The euhedral arsenopyrite grains studied show an early enrichment in $\mathrm{Co}, \mathrm{Ni}$, $\mathrm{Te}, \mathrm{Se}, \mathrm{Mo}$, and $\mathrm{Sb}$ (Fig. 12) which is reflected in both the elemen- 

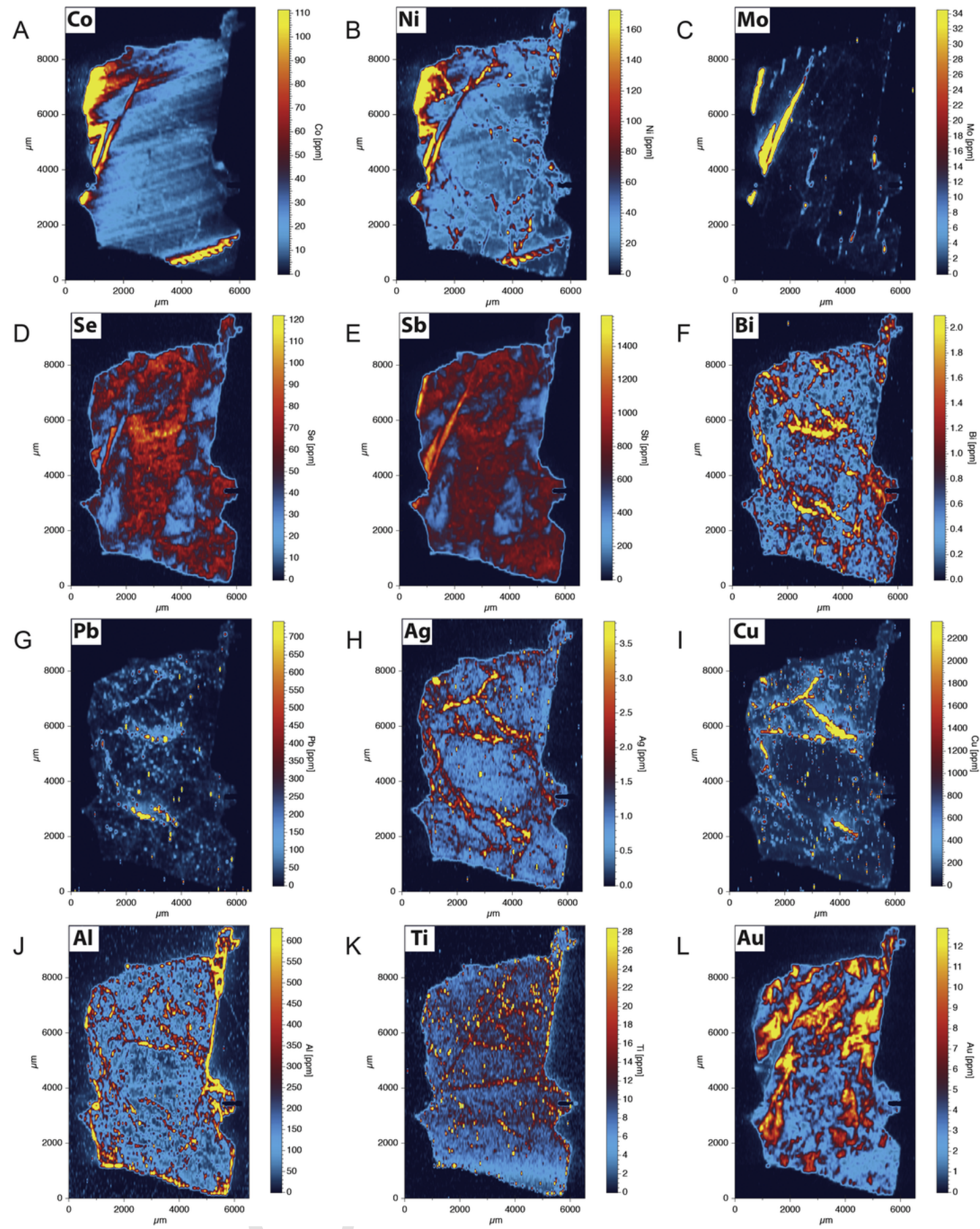

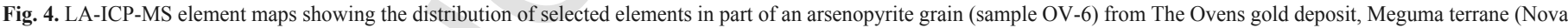

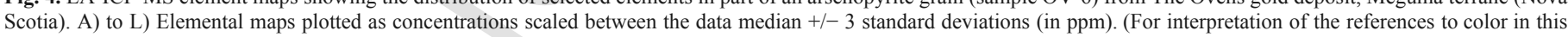
figure legend, the reader is referred to the web version of this article.)

tal distribution maps (e.g., Dufferin, Touquoy, Cochrane Hill; Figs. 5, 6 and 7, respectively) and traverse patterns (e.g., Cochrane Hill, Upper Seal Harbour, Tangier and Caribou deposits; Figs. 7 to 11, respectively). The maps and traverses suggest this elemental enrichment overlaps the growth of the host phase. Moreover, traverse analyses from the Caribou samples (Figs. 10, 11) suggest that $\mathrm{Au}$, and to a lesser extent Ag, also mimic this growth zoning and were introduced early as nanoparticles or a background enrichment (Figs. 10, 11). Importantly, the concentration of Co and Ni in an "external rim" in some cases (i.e., Touquoy, Cochrane Hill deposits; Figs. 6 and 7, respectively) are also interpreted to reflect primary growth zoning.

Selenium, Mo, Sb, and to a lesser extent Ni and Te all show similar distribution patterns, which either mimic or locally overprint the zoning of the host arsenopyrite. This elemental distribution also reflects a primary feature. Traverse and some map analyses show that the putative earlier background concentrations of $\mathrm{Au}$ appear to be relatively antithetic to Mo zonation (e.g., Beaver Dam, The Ovens, Touquoy, Cochrane Hill, and Caribou deposits; Figs. 3, 4, 6, 7, 
A

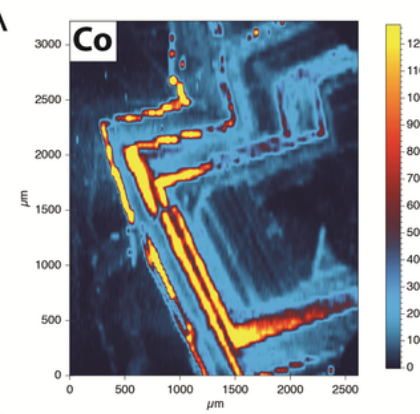

D

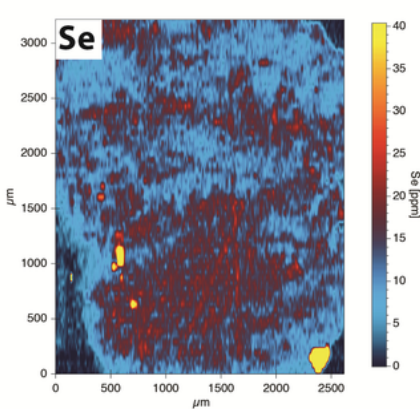

G

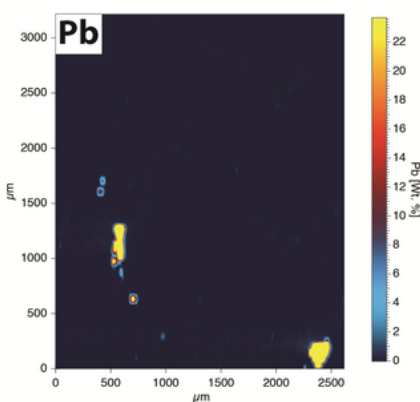

$J$

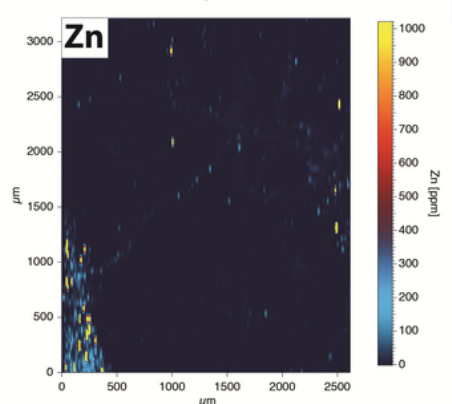

B

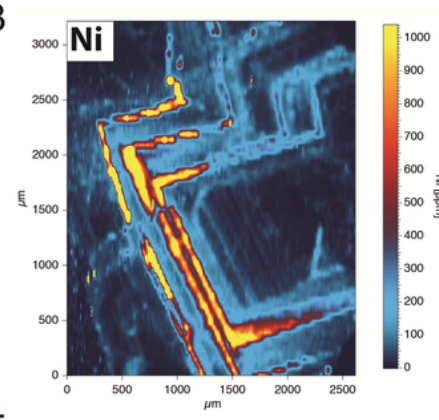

$\mathrm{E}$

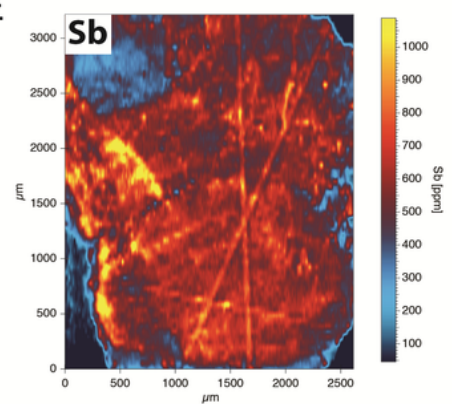

$\mathrm{H}$

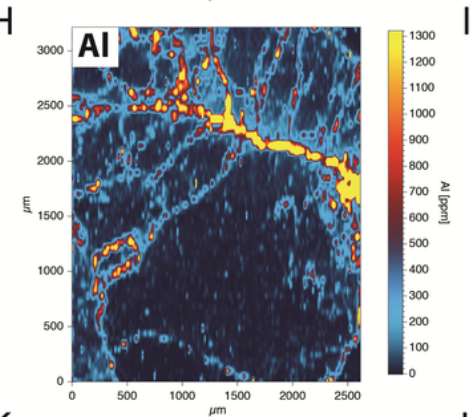

K

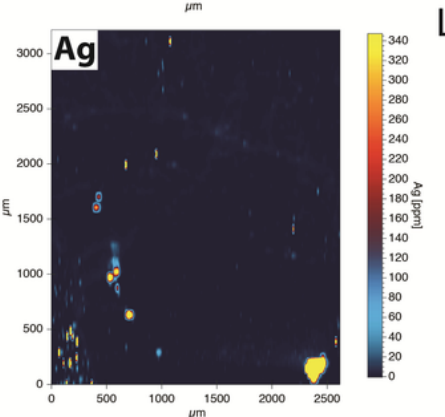

C

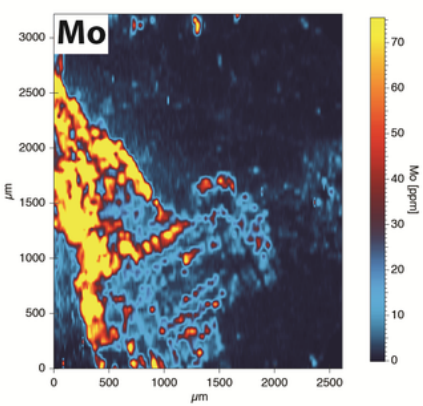

$\mathrm{F}$

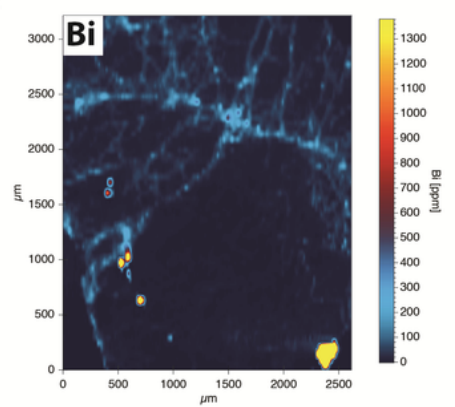

I

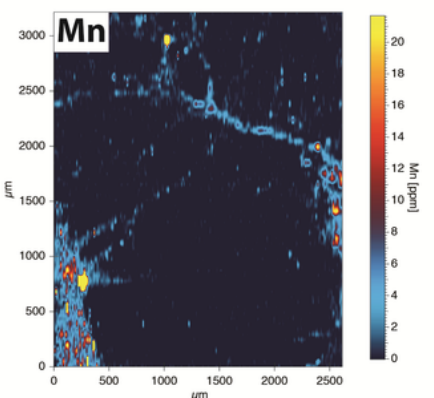

L

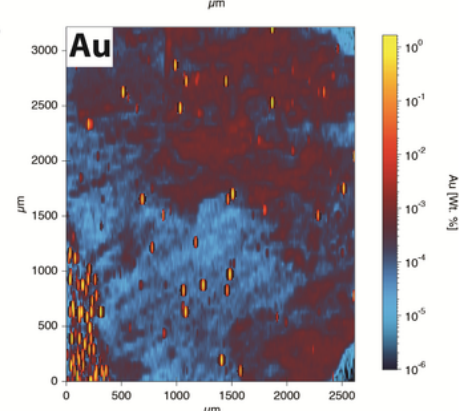

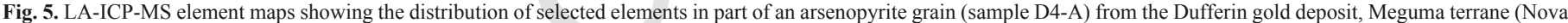

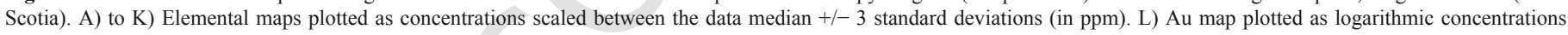

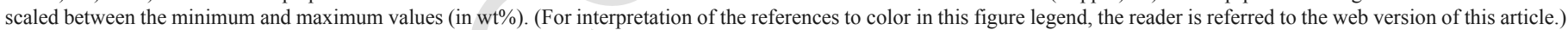

10,11 , with it particular well illustrated for the Dufferin deposit sample (Fig. 5)).

Several events that post-date the primary growth of arsenopyrite discussed above are recognized in all the samples, as illustrated by: 1) an early $\mathrm{Bi}, \mathrm{Pb}, \mathrm{Cd}, \mathrm{In}, \mathrm{Se}, \mathrm{Ag}, \mathrm{Au}$ and locally $\mathrm{Zn}$ (i.e., Beaver Dam, Touquoy and Cochrane Hill, Caribou deposits; Figs. 3, 6, and 7, respectively; but note that In and Cd are lacking in the maps shown) element assemblage associated with an early fracture set (F1 assemblage herein). This assemblage is also associated with formation of galena and likely sphalerite either as micro-inclusions or as fracture-fillings (Fig. 13A, B, C, D). Further support of this was presented by Kontak and Smith (1993) in their study of the Beaver Dam de- posit; and 2) a later stage of enrichment of a broad suite of elements that includes Al, Ti, V, Mn, Au, Ag, (e.g., Beaver Dam, Dufferin and Touquoy; Figs. 3, 5, 6, respectively; also $\mathrm{Cr}$, W, Sn which are not shown in the maps), Zn (e.g., Dufferin and Touquoy; Figs. 5 and 6, respectively), $\mathrm{Cu}$ (e.g., Beaver Dam, Cochrane Hill; Figs. 3 and 7, respectively). This later elemental assemblage is associated either with a later fracture set (F2 assemblage herein), which clearly crosscuts the earlier set (cf., note F1 in Beaver Dam; Fig. 3), or with an external rim on the arsenopyrite (e.g., Touquoy; Fig. 6). This elemental assemblage is reflected mineralogically by the presence of various inclusions or fracture-fillings in arsenopyrite (e.g., rutile, ilmenite, chlorite; Fig. 13D, E, F). Furthermore, examination of the elemen- 

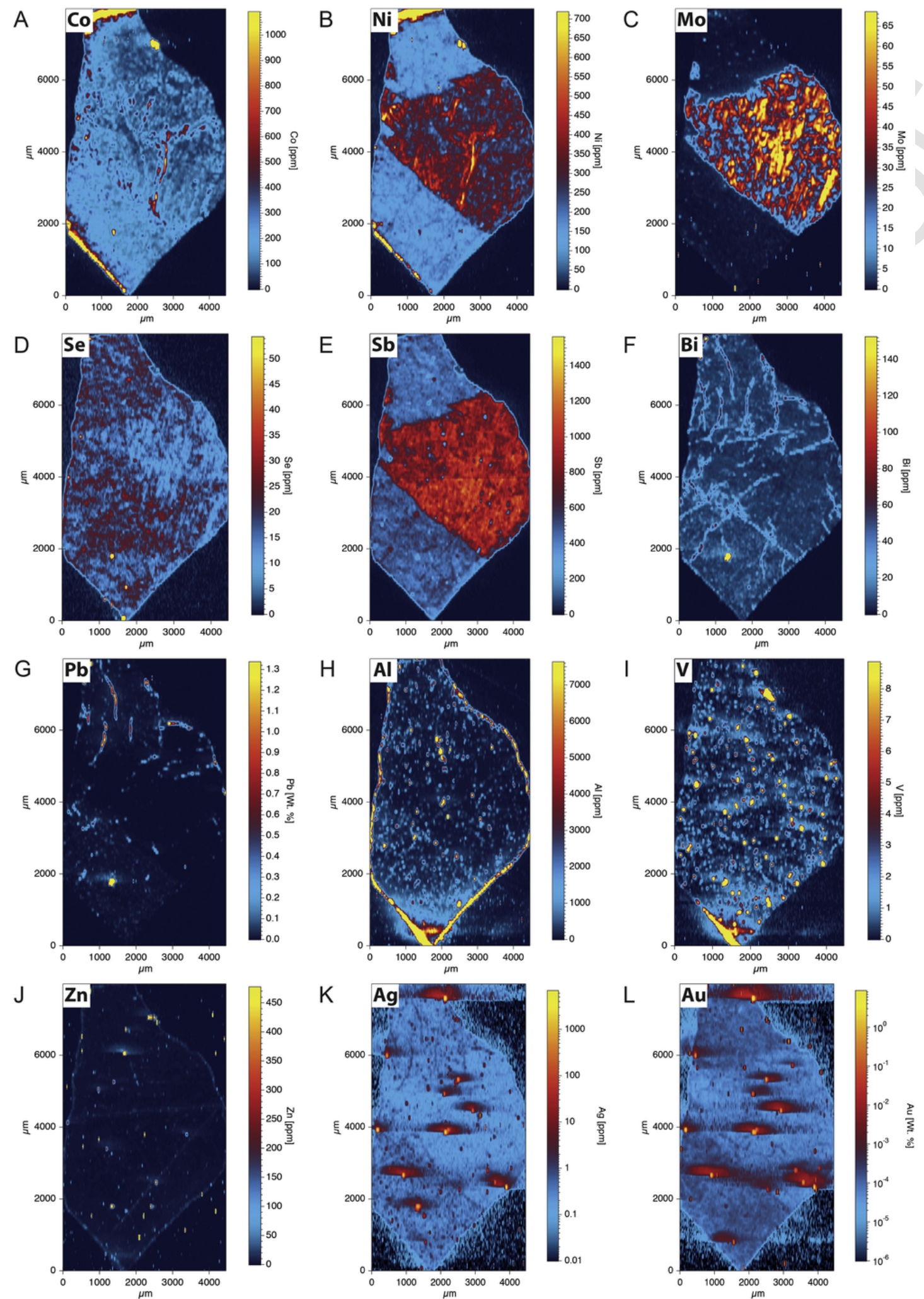

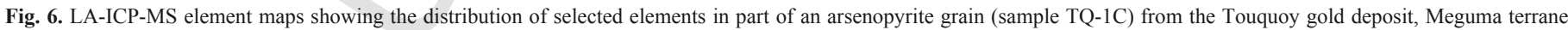

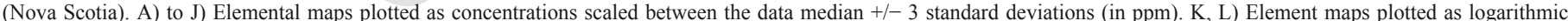

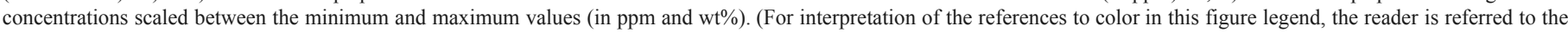
web version of this article.) 

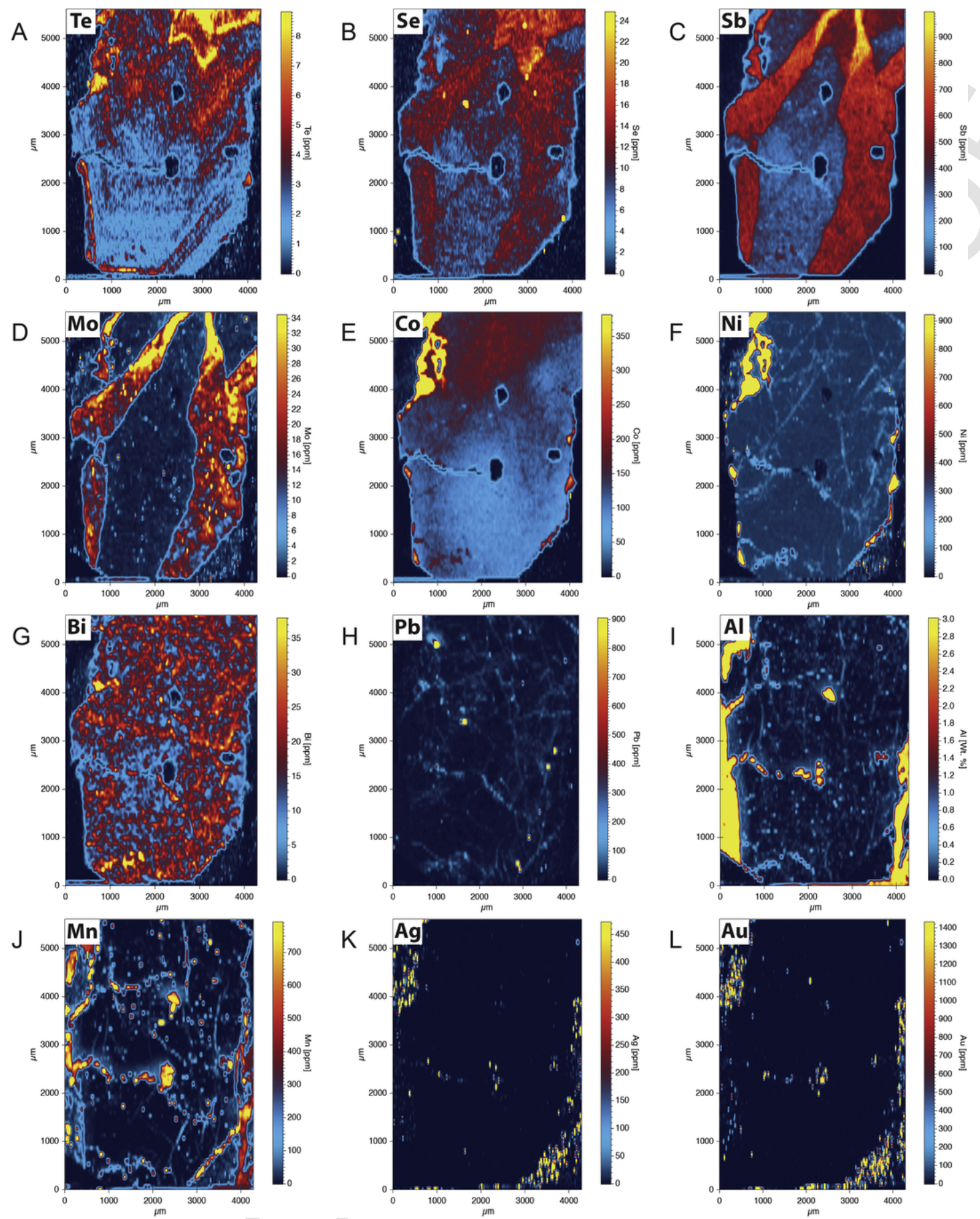

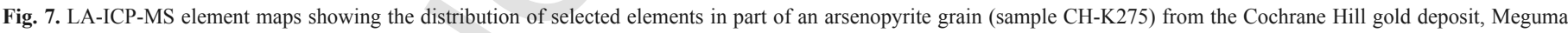

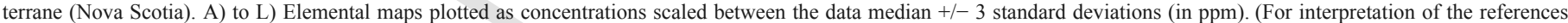
to color in this figure legend, the reader is referred to the web version of this article.)

tal distribution analyses, minor concentrations of this latter element association can be observed in the early fracture set, which suggests reactivation and mobilization of these elements out of these earlier fractures during continued or subsequent fluid circulation (e.g., Beaver Dam, Upper Seal Harbour, and Tangier). In addition, Ni may show a later stage of superimposition along the F1 and F2 fractures sets (cf. Beaver Dam, Touquoy; Figs. 3 and 6, respectively), which further suggests a post-crystallization history of elemental mobilization.
Regarding $\mathrm{Au}$ and $\mathrm{Ag}$ concentrations in arsenopyrite, we note the F1 and F2 fracture sets are mainly associated with micro-inclusions, as demonstrated by SEM observations (e.g., Beaver Dam, Touquoy, Cochrane Hill; Fig. 13), and higher concentrations of these elements than in the arsenopyrite core $(>10 \mathrm{ppm})$, as is clearly evident in traverse analyses. Thus, the element maps and traverses, which offer complementary information, provide evidence for a late-stage enrichment of $\mathrm{Au}$ and $\mathrm{Ag}$ along both fracture sets: 1) F1 with a Bi-Pb-Cd- 
Table 4

A compilation of the LA-ICP-MS maps and traverses produced from the various analyzed arsenopyrite grains and the location of the data presented in this paper.

\begin{tabular}{|c|c|c|c|c|}
\hline Deposits & Maps & Taverses & Figures & Appendix \\
\hline $\begin{array}{r}\text { Beaver } \\
\text { Dam }\end{array}$ & LC-12-16 & & Fig. 2 & \\
\hline The Ovens & OV-6 & & Fig. 3 & \\
\hline Dufferin & D4-A & & Fig. 4 & \\
\hline Touquoy & TQ-1C & & Fig. 5 & \\
\hline $\begin{array}{l}\text { Cochrane } \\
\text { Hill }\end{array}$ & $\begin{array}{l}\mathrm{CH}- \\
\mathrm{K} 275\end{array}$ & CH-K092 & Fig. 6 & Fig. A \\
\hline $\begin{array}{c}\text { Upper Seal } \\
\text { Harbour }\end{array}$ & & DM-91-12_1 DM-91-12_2 & Fig. 7 & Fig. B \\
\hline Tangier & & TG-01 & Fig. 8 & \\
\hline \multirow[t]{5}{*}{ Caribou } & & CAR-88-47_1 & & Fig. C \\
\hline & & CAR-88-47_2 & & Fig. D \\
\hline & & CAR-88-47_1 & & \\
\hline & & CAR-88-7C_2 & Fig. 9 & \\
\hline & & CAR-88-7C_3 & Fig. 10 & \\
\hline
\end{tabular}

In elemental assemblage; and 2) F2 with an Al-Ti-V-Cr-Mn elemental assemblage. This late-stage precious-metal endowment relates to the post-crystallization stage of the arsenopyrite grains and reflects a potential upgrading of $\mathrm{Au}$ and to a lesser extent Ag due to either continued and or subsequent fluid circulation. Similar findings have been noted and similarly interpreted by, for example, Wagner et al. (2007) and Lawley et al. (2015).

\subsection{Elemental distributions and Au mineralizing events}

The evaluation of original $\mathrm{Au}$ distribution in arsenopyrite (i.e., the primary gold event) and its potential upgrading can be assessed using binary element plots of $\mathrm{Au}$ versus $\mathrm{Ag}$, which are further enhanced using color coding, as a proxy for concentration, for single elements or element associations (Gourcerol et al., 2018b). Distribution of the TSD data reveals the relationships between gold concentration (i.e., its tenor) and the relative timing of its sequestering into the host arsenopyrite. Based on this treatment of the TSD data, three dis-

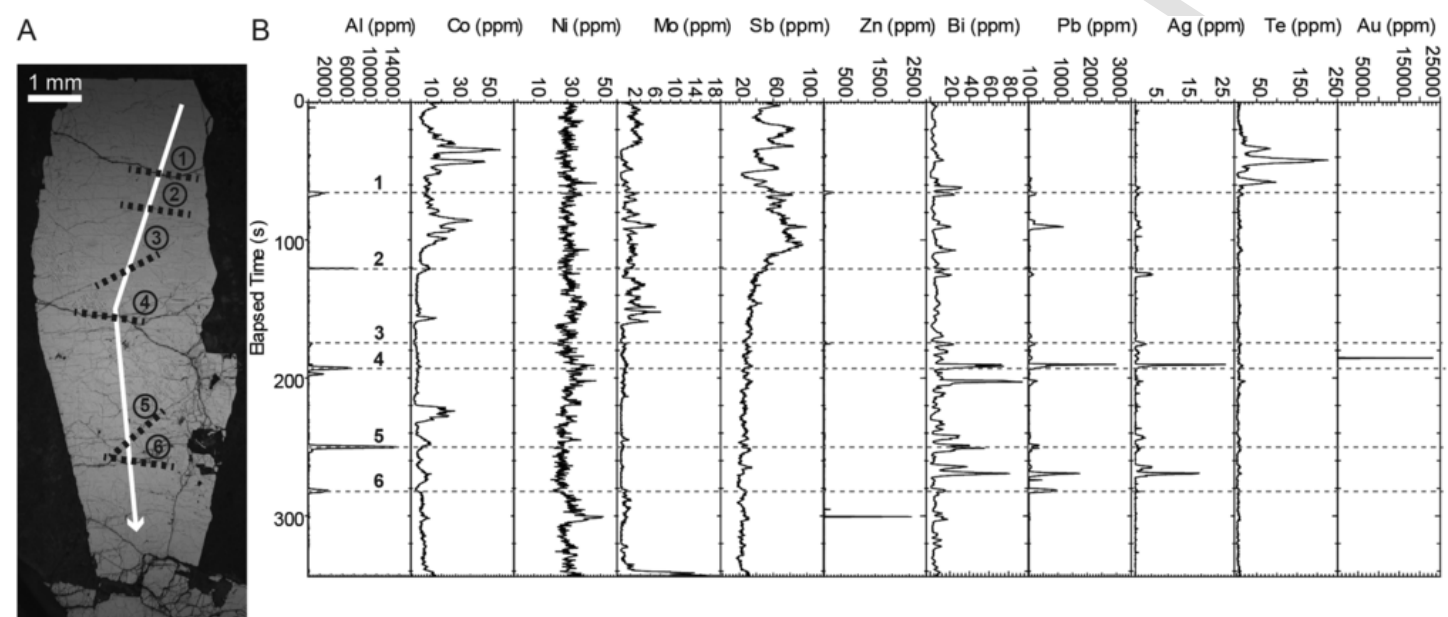

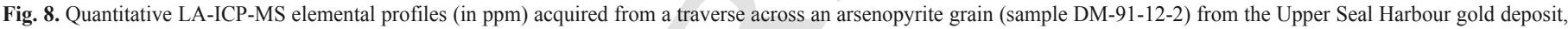

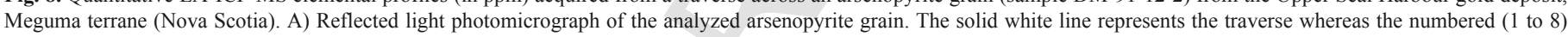

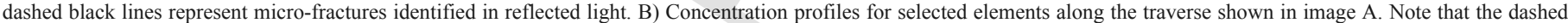

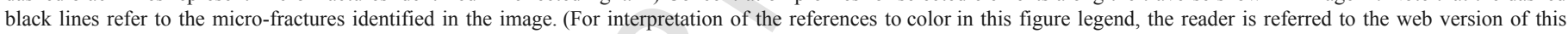
article.)

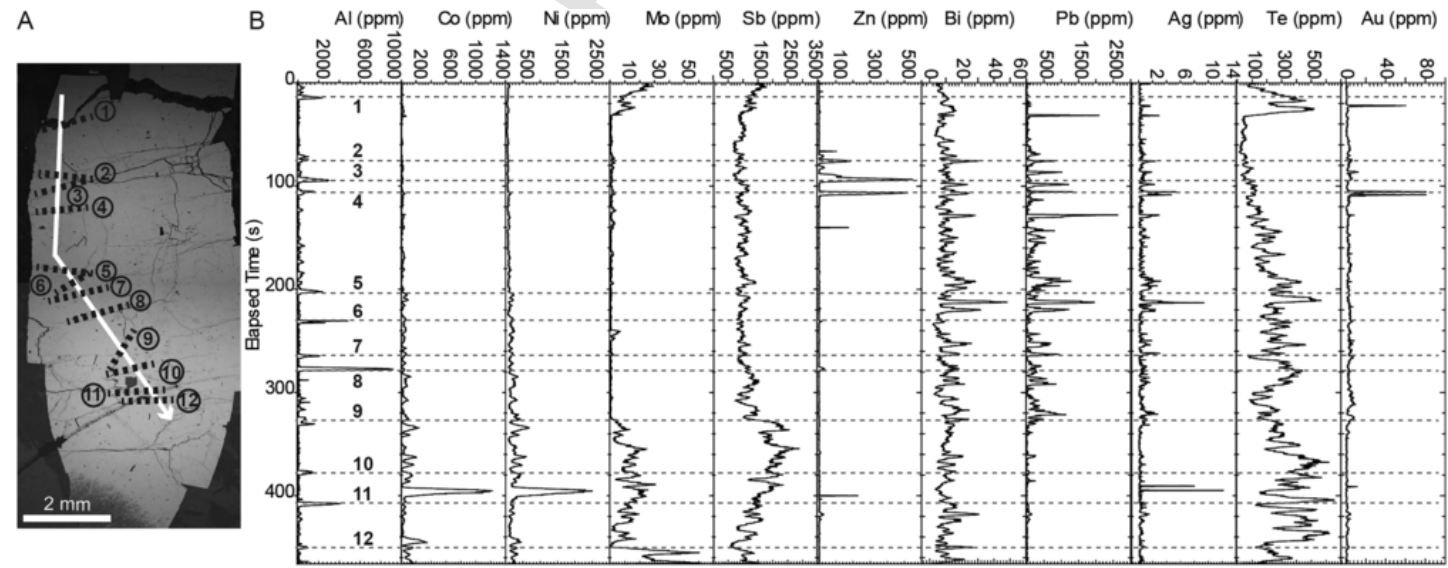

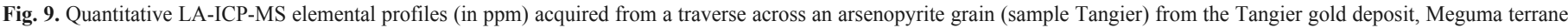

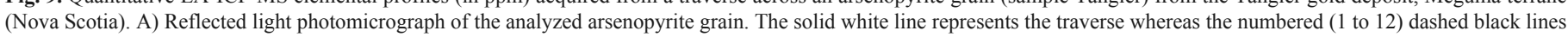

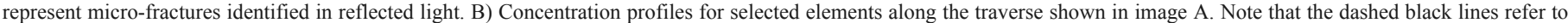
the micro-fractures identified in image A. (For interpretation of the references to color in this figure legend, the reader is referred to the web version of this article.) 

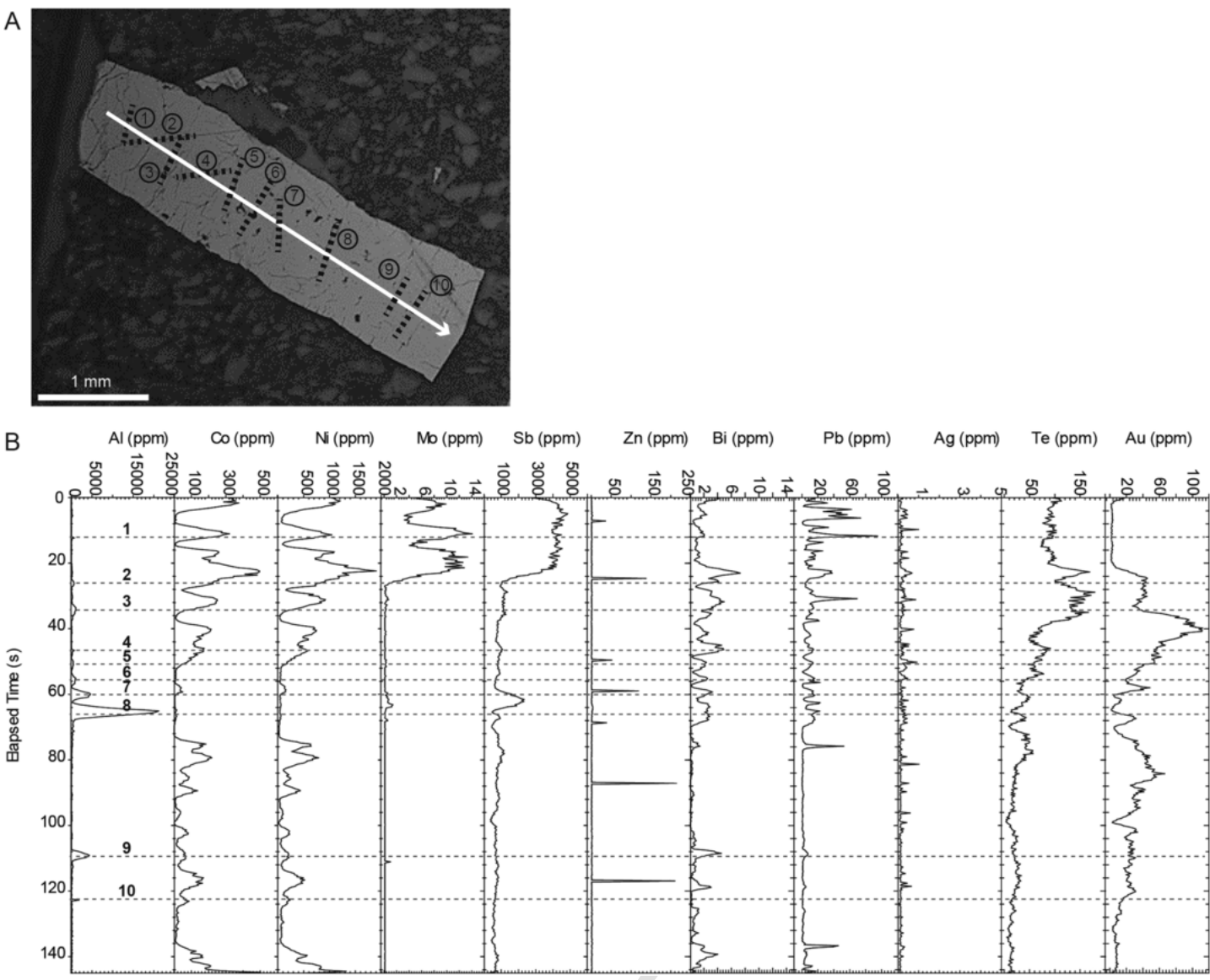

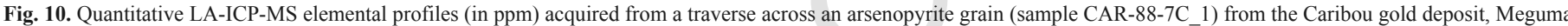

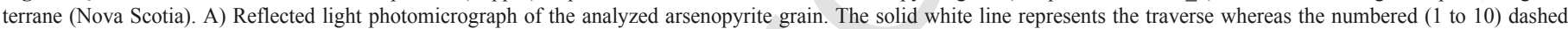

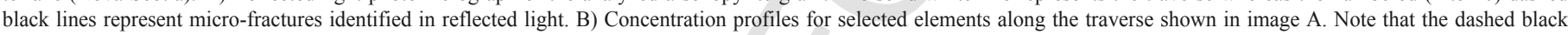
lines refer to the micro-fractures identified in image A. (For interpretation of the references to color in this figure legend, the reader is referred to the web version of this article.)

tinct groupings of deposits are identified based on data distribution and precious-metal tenors.

The first group, illustrated by Beaver Dam and Touquoy deposits (Figs. 14 and 15, respectively), suggests a strong correlation of Au and $\mathrm{Ag}$ tenors (with a consistent 10:1 ratio). The data confirm that $\mathrm{Au}$ and $\mathrm{Ag}$ (both $<10 \mathrm{ppm}$ ) were initially concentrated as invisible metals, that is, either structurally-bound or present as nanoparticles (Gourcerol et al., 2018b), during the primary growth of the arsenopyrite whereby Co and $\mathrm{Ni}$ are used as proxies for its early growth (Figs. 14A, B, 15A). $\mathrm{A} \mathrm{Mo}, \mathrm{Sb}$ and $\mathrm{Se}$ element assemblage, which represents a relatively late-stage primary feature in both deposits, shows a slight increase in $\mathrm{Au}$ and $\mathrm{Ag}$ to about $100 \mathrm{ppm}$ (Figs. 14C, 15B, C). F1 fractures associated with the $\mathrm{Bi}-\mathrm{Pb}-\mathrm{In}-\mathrm{Cd}$ element assemblage are associated with an increase of $\mathrm{Ag}$ and Se tenors (up to $1000 \mathrm{ppm}$; Fig. 14E, 15D), whereas an Al-Ti-V-Cr-Mn elemental assemblage (i.e., later F2 fractures for Beaver Dam deposit and the external rim for the Touquoy deposit) is associated with an increase in both $\mathrm{Au}$ and Ag tenors (up to $10 \mathrm{wt} \%$ for $\mathrm{Au}$ and $1 \mathrm{wt} \%$ for $\mathrm{Ag}$ ) along with a $10: 1$ ratio and probable formation of gold micro-inclusions in the fracture set (Figs. 13E, $\mathrm{F}, 14 \mathrm{~F}, 15 \mathrm{E}$ ). Lastly, there is the presence, albeit minor, of Ag-poor micro-inclusions of gold in both samples (Fig. 14A, 15A).

A second group, which includes The Ovens and Dufferin deposits (Figs. 16 and 17, respectively), shows a different elemental distribution with the most notable difference compared to that for Beaver Dam and Touquoy being the absence of a well-defined and uniform $\mathrm{Au}$ Ag relationship (i.e., the 10:1 ratio). There is however, at least for the Dufferin dataset, the presence of Ag-poor micro-inclusions of gold, which are lacking at The Ovens (Figs. 16A, 17A). Nevertheless, as in the previous plots, common elemental associations and trends are seen in the data for these two deposits such as: 1) presence of primary $\mathrm{Au}$ and $\mathrm{Ag}$ in the arsenopyrite (both up to $10 \mathrm{ppm}$; Figs. 16A to $\mathrm{C}$, $17 \mathrm{~A}$ to $\mathrm{C})$; 2) a Bi-Pb-In-Cd element assemblage, present either as inclusions or in fracture sets, that is associated with an increase of $\mathrm{Ag}$ and minor Se tenors (e.g., up to $1 \mathrm{wt} \% \mathrm{Ag}$ for the Dufferin deposit) along with consistent $\mathrm{Au}$ values (up to $10 \mathrm{ppm}$ ). Note that for Dufferin there is a higher proportion of data defining this latter trend than for any other data set (Fig. 17D); and 3) a relatively late fracture set or late-stage rim overgrowth with an Al-Ti-V-Cr-Mn element association, which is slightly correlated with a higher Au tenor (up to $100 \mathrm{ppm}$ for the Dufferin deposit (Fig. 17E) versus $10 \mathrm{ppm}$ for The Ovens (Fig. $16 \mathrm{~F})$ ).

Finally, data from the Cochrane Hill deposit (Fig. 18) defines a third group which differs from the previous datasets in regard to the absence of Ag-rich outliers and a poorly defined Au:Ag ratio, but it does show the presence of Ag-poor micro-inclusions of gold. The primary nature of $\mathrm{Au}$ and $\mathrm{Ag}$ is however still well defined by the data with up to $100 \mathrm{ppm}$ of each. In addition, the data do not define the $\mathrm{Bi}-\mathrm{Pb}-\mathrm{Cd}-\mathrm{In}$ element association with $\mathrm{Ag}$ enrichment, as seen in the other deposits, but does show the Al-Ti-V-Cr-Mn element association related to minor (e.g., Beaver Dam and Touquoy deposits) $\mathrm{Au}$ and $\mathrm{Ag}$ enrichment (Fig. 18D; up to $1000 \mathrm{ppm}$ ). 


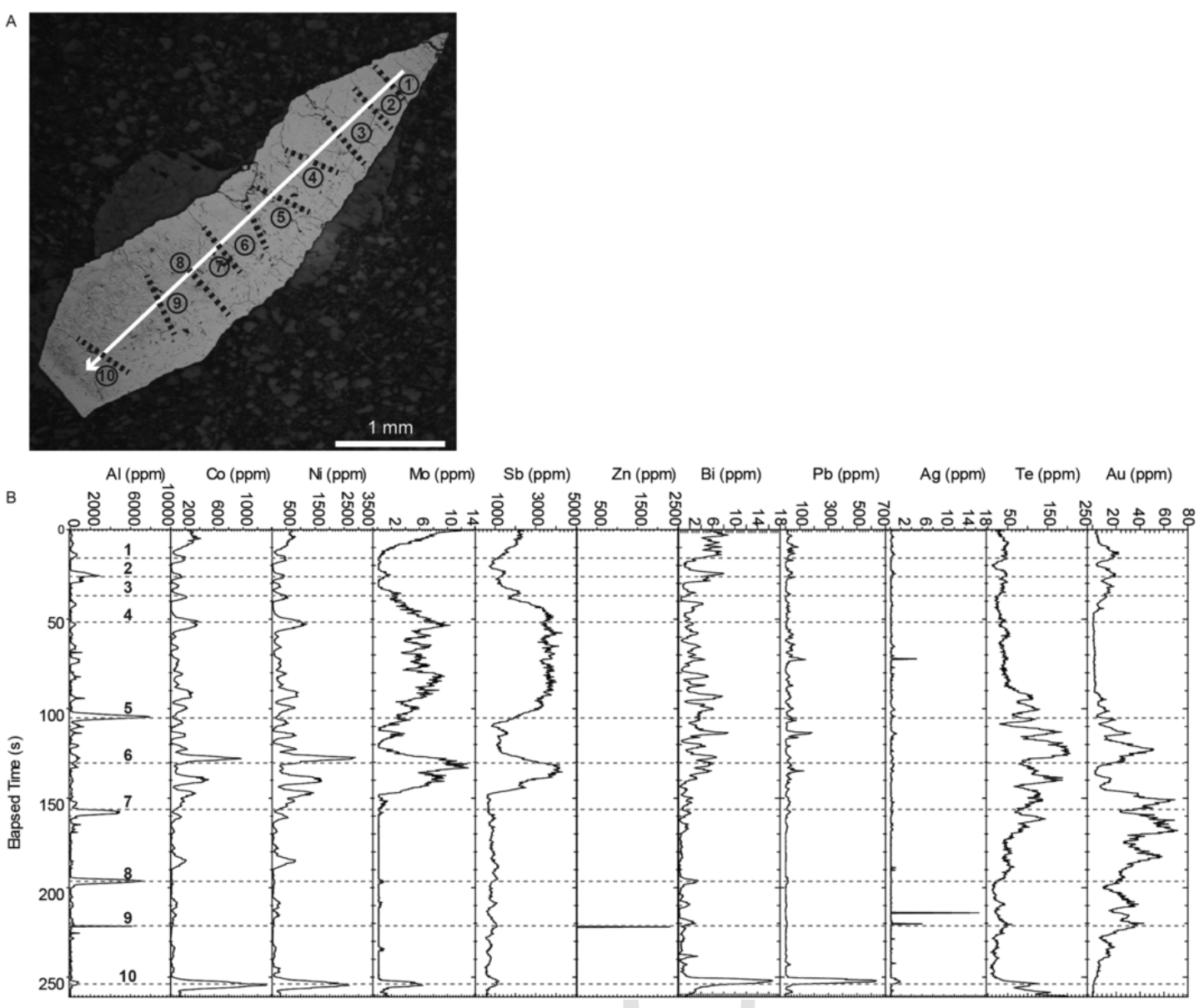

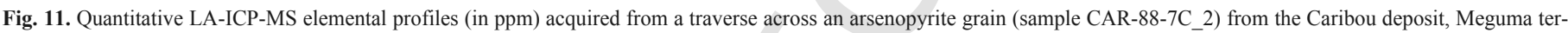

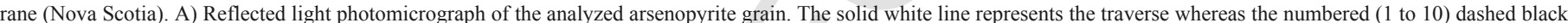

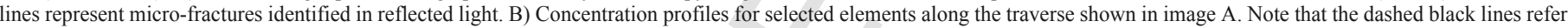
to the micro-fractures identified in image A.

Based on the observations for the various binary element plots discussed above, at least two distinct gold events are identified: 1) the first is associated with primary sulfide growth and reflects a continued $\mathrm{Au}$ input, at times increasing until the latest stage of arsenopyrite growth (i.e., coincident with Mo-Se-Sb endowments); and 2) a second event, which varies in its gold tenor and is similar (Beaver Dam and Touquoy) or dissimilar (other deposits) regarding its $\mathrm{Au}: \mathrm{Ag}$ ratio and is associated with an Al-Ti-V-Cr-Mn elemental assemblage. This latter association reflects upgrading of the tenor of $\mathrm{Au}$ and is seen in all the deposits along with a good correlation between primary and late-stage secondary element associations (e.g., Figs. 14H, 15G, H, $16 \mathrm{G}, \mathrm{H})$. Importantly, the presence of the Ag-, Au-Ag- and Au-rich outliers (Figs. 14 to 18), which reflect micro-inclusions, may be related to post-crystallization events and/or a continuation of the primary mineralizing system. Moreover, the change in the Au:Ag ratio of the former population may be attributed to a zone refining process. As for the Bi-Pb-Cd-In-Ag assemblage, which is Au poor, this is attributed to remobilization (Figs. 15H, 16G, 17G, 18F), hence the association with elevated Al-Ti-V-Cr-Mn, or subsequent upgrading (Fig. $14 \mathrm{G}$ ) of earlier Au tenors as confirmed by Au micro-inclusions along the F1 fracture set in the Beaver Dam deposit.

Importantly, strong to good correlation between $\mathrm{Bi}-\mathrm{Pb}-\mathrm{Cd}-\mathrm{In}$ and Al-Ti-V-Cr-Mn element associations with respect to Au (Figs. 15G, $\mathrm{H}, 16 \mathrm{G}, 17 \mathrm{G})$ suggests the exploiting of fracture sets, either reactivated or newly formed, during subsequent fluid circulation, as sug- gested in the previous section. An apparent anomaly here is the apparent lack of $\mathrm{Au}$ enrichment (i.e., maximum at about $10 \mathrm{ppm}$ ) for The Ovens sample compared to the other analyzed samples despite the evidence of this later fluid event.

Quantitative element distribution data from traverses, rather than elemental maps, were acquired for samples from the Upper Seal Harbour, Tangier and Caribou deposits. These data show elemental distributions similar to those seen in the Beaver Dam and Touquoy deposits (Table 4; Figs. 8 to 11, Figs. B to E), such as primary Au enrichment, $\mathrm{Au}$ upgrading, the $\mathrm{Bi}-\mathrm{Pb}-\mathrm{Cd}-\mathrm{In}-\mathrm{Ag}$ association, and $\mathrm{Au}$ enrichment correlated with an Al-Ti-V-Cr-Mn. We also note that the presence of spikes in elements such as Te-Bi-Pb, $\mathrm{Zn}$ and Te (Upper Seal Harbour; Fig. 8), $\mathrm{Pb}, \mathrm{Pb}-\mathrm{Ag}$, and $\mathrm{Zn}$ (Tangier; Fig. 9), and $\mathrm{Pb}, \mathrm{Zn}$, and $\mathrm{Ag}$ (Caribou; Figs. 10, 11) likely indicate the presence of micro-inclusions. For these samples, the Au versus Ag plots for arsenopyrite (Fig. 19) reveal similarities to the three types of plots discussed previously in terms of either a well-defined Au:Ag ratio (e.g., Cochrane Hill data; Fig. 19A) versus the lack thereof for Tangier, Upper Seal Harbour and Caribou samples (Fig. 19B, C, and D, respectively). In addition, there is a large range in Au enrichment with the Cochrane Hill samples showing the highest values (10,000 ppm, Fig. 19A), whereas the Caribou data show the highest values for inferred primary Au enrichment with up to $100 \mathrm{ppm} \mathrm{Au}$ (Fig. 19D) versus $<10 \mathrm{ppm}$ for Tangier and Upper Seal Harbour (Fig. 19B and C, respectively). 


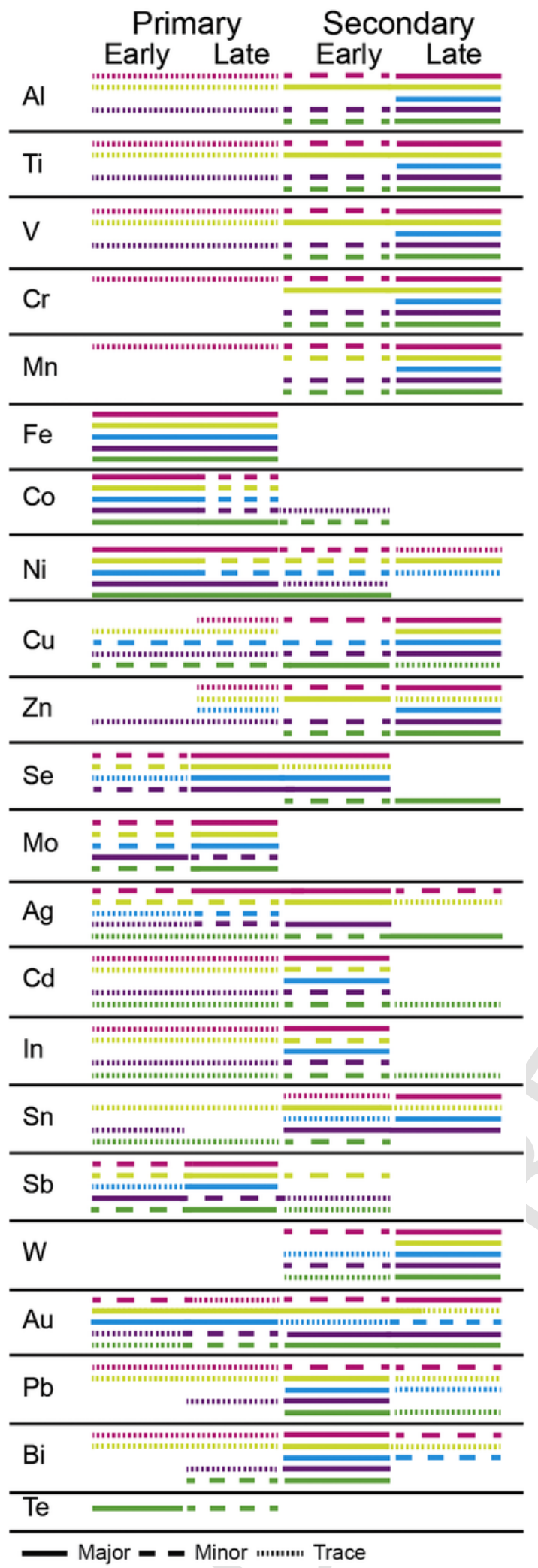

Fig. 12. Compilation of the inferred elemental paragenesis for the Meguma gold deposits studied based on the integration of reflected light petrographic studies and quantitative LA-ICP-MS element distribution maps produced for arsenopyrite grains. The color coding represents the Beaver Dam (pink), The Ovens (yellow), Dufferin (blue), Touquoy (purple) and Cochrane Hill (green) deposits. Note that, in general, there is a broadly similar elemental paragenesis for each of the deposits studied. (For interpretation of the references to color in this figure legend, the reader is referred to the web version of this article.)

\section{Discussion}

In this study, arsenopyrite samples from several gold deposit sites across the Meguma terrane of Nova Scotia were studied in order to constrain several important aspects of gold metallogeny in general and metasedimentary-hosted deposits specifically. The application of data derived from element distribution maps, element profiles based on traverses, and a variety of multi-element plots using TSD data derived from continuous LA-ICP-MS analysis provides the basis for addressing several important issues that pertain to the nature of the gold mineralization: 1) elemental paragenesis and element associations; 2) nature of gold and its possible remobilization or upgrading; 3) significance of the Au:Ag ratio; 4) possible wall-rock influence inferred from the whole-rock, isotopic and mineralogical data bases; and 5) the implications of the data for the source of gold and gold mineralizing processes in a gold metallogenic province.

\subsection{Elemental paragenesis and associations in the Meguma deposits}

The integration of petrographic observations and SEM-EDS imaging with the elemental maps and the traverses together with the multi-element plots provide the basis for establishing elemental paragenesis. Comparison of the paragenesis of the eight studied deposits indicates very similar features and suggests their common evolution and thus strongly argues for a similar fluid history (Figs. 12, 20).

The arsenopyrite grains studied reveal a protracted and complex growth history with two very distinct early mineralizing episodes (i.e., primary events). An initial stage of primary growth is reflected by oscillatory changes in the $\mathrm{Co}-\mathrm{Ni}(-\mathrm{Te})$ contents during the initial stage of arsenopyrite nucleation and subsequent development. This type of zonation has been reported in other studies of arsenopyrite (e.g., Cathelineau et al., 1989; Morey et al., 2008; Cook et al., 2013) and has been attributed to the influence of the primary hydrothermal fluid, rather than a later metamorphic fluid (e.g., Shore and Fowler, 1996), with the alternating zones reflecting fluctuations in fluid chemistry coupled with a low diffusion rate in the crystal, and hence preservation of the zoning, and possibly varying temperature. The second mineralizing episode, which has a Mo-Se-Sb element association, is inferred paragenetically to be later in the initial growth history (Fig. 12); it locally follows the growth zoning but mainly shows a non-uniform distribution which may suggest precipitation under near-equilibrium conditions with uniform mixing (Krinov, 2008). Importantly, preservation of this initial oscillatory zoning in the arsenopyrite suggests that diffusional equilibration did not affect these domains. In addition to the above mineralizing events, two later stage fluid events, as illustrated by fracture-controlled element associations (i.e., F1, F2), affected the arsenopyrite grains: 1) early F1 fractures with a $\mathrm{Bi}-\mathrm{Pb}-\mathrm{Cd}-\mathrm{In}-\mathrm{Ag}$ element association; and 2) later F2 fractures, which crosscut $\mathrm{F} 1$, which have an Al-Ti-V-Cr-Mn element association. The early $\mathrm{Bi}-\mathrm{Pb}-\mathrm{Cd}-\mathrm{In}-\mathrm{Ag}$ bearing fluid is associated with the upgrading of $\mathrm{Ag}$ tenors along with $\mathrm{Se}$, and formation of galena micro-inclusions. The later Al-Ti-V-Cr-Mn elemental association is related to Au upgrading, both where Au:Ag is 10:1 and Ag-poor, and involved the local formation of visible gold grains in these fractures along with rutile, chlorite and ilmenite.

Thus, the integration of the elemental maps with ore petrology and SEM-EDS observations provide evidence for ore-system longevity and complexity, in this case across an entire metallo- 

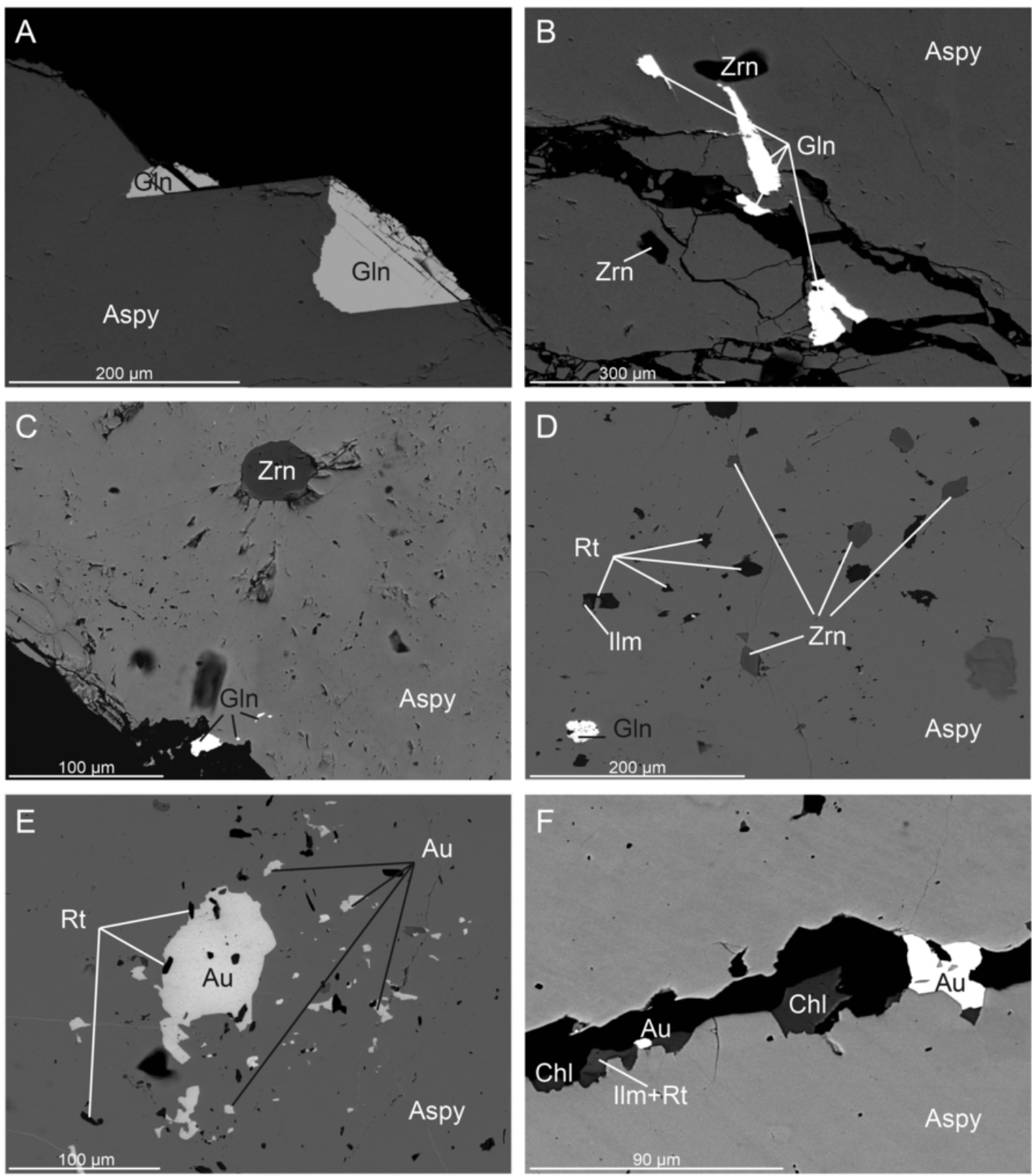

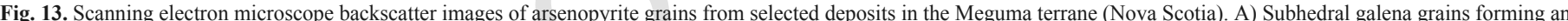

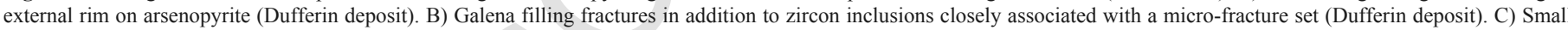

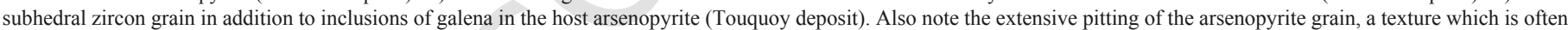

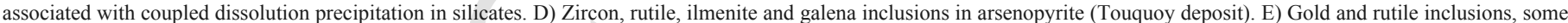

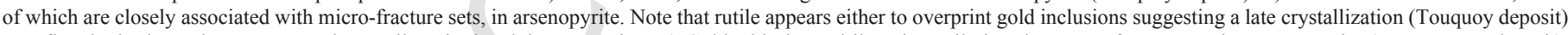

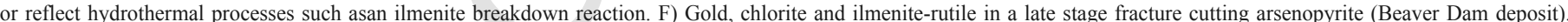

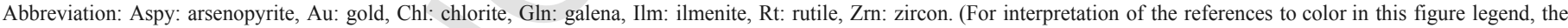
reader is referred to the web version of this article.)

genic terrane based on our sampling (regarding geochemistry of the arsenopyrite grains). The establishment of such elemental associations and paragenesis has not previously been possible and, as shown here, provides the means to demonstrate a commonality to mineralizing processes among similar ore deposit settings within a given metallogenic terrane. The previous use of bulk-rock chemistry via traditional whole-rock analysis is clearly flawed in terms of establishing elemental associations, as illustrated by the complexities revealed in the elemental maps shown above.

\subsection{Nature and implications of gold mineralizing events}

Elemental paragenesis established from both the element distribution maps and traverses and the derived Au versus Ag plots using the TSD data suggest two distinct gold events: 1) the first is evident from the presence of invisible gold or inferred nanoparticles; and 2) the second is seen as an association of Au enrichment, sometimes as visible particles, with an Al-Ti-V-Cr-Mn elemental association concentrated along fractures (i.e., the F2 set). 

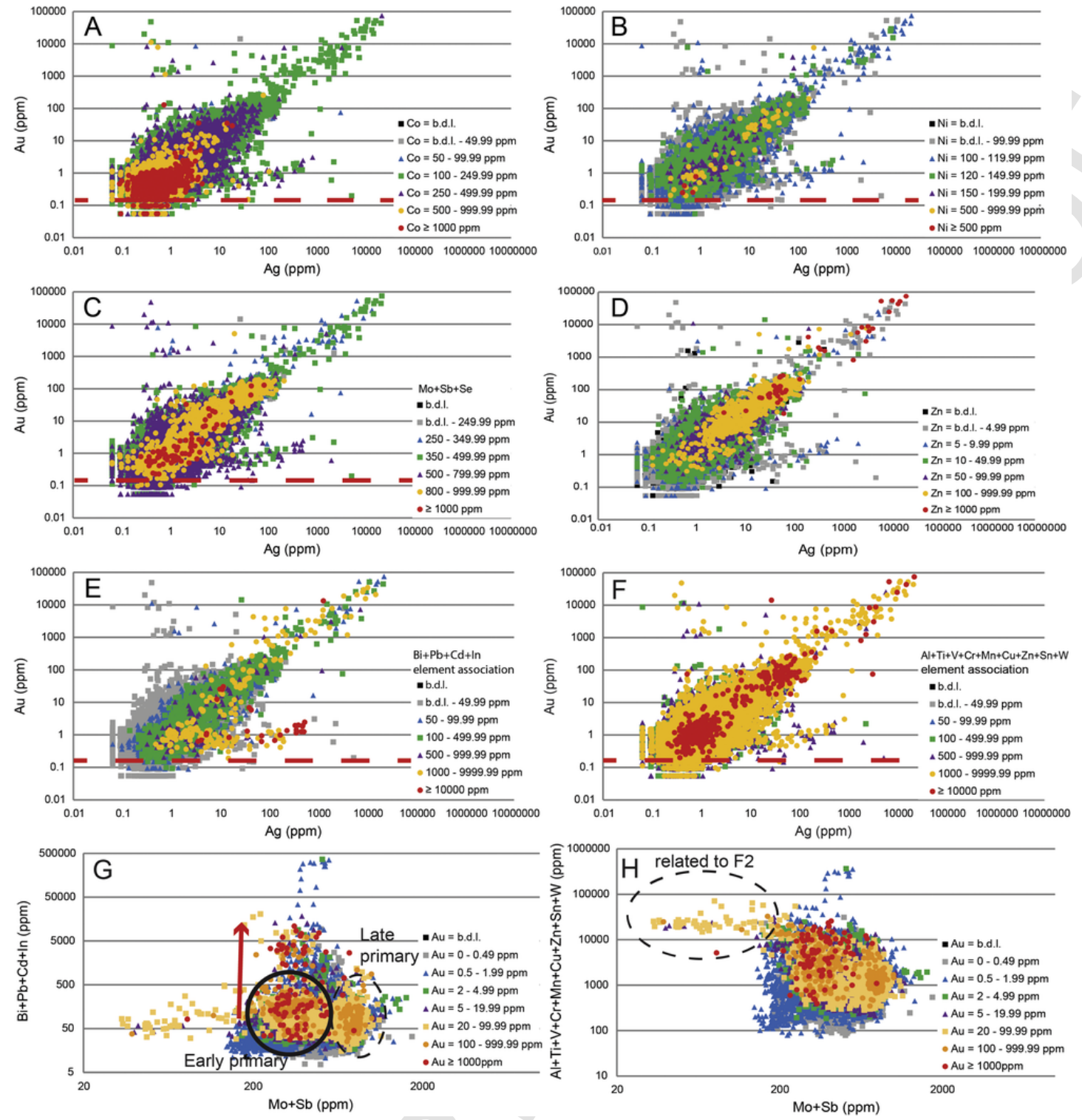

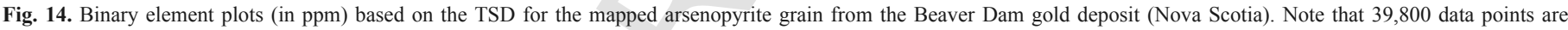

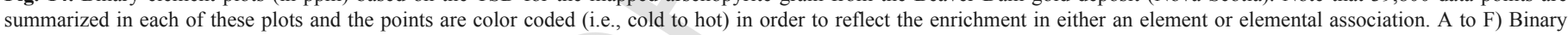

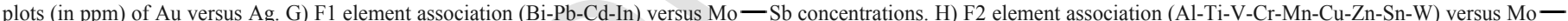

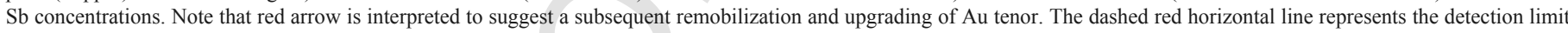

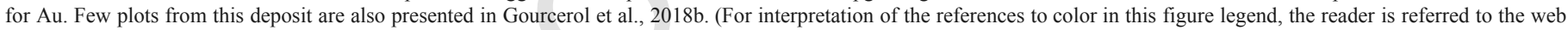
version of this article.)

The first $\mathrm{Au}$ event coincided with the growth of arsenopyrite, which was monitored by using $\mathrm{Ni}$ and $\mathrm{Co}$ as proxies of primary growth. In this early stage of arsenopyrite, gold is inferred to have been deposited either as invisible gold (e.g., Reich et al., 2005) or as nanoparticles (Fougerouse et al., 2016b) within oscillatory $\mathrm{Co}-\mathrm{Ni}$ zoned arsenopyrite; the traverse mode analyses provide a good representation of this oscillatory zoning via the coupling of Co and $\mathrm{Ni}$ (e.g., Figs. 10 and 11). Gold content in such zones is mostly present at values $<10 \mathrm{ppm}$, but can in some cases (i.e., Caribou, Beaver Dam, Touquoy) extend up to $100 \mathrm{ppm}$ (Figs. 10, 14, and 15, respectively). This early event reflects a continued and uniform proportion of $\mathrm{Au}$, although at times increasing, until the latest stage of sulfide crystallization, as marked paragenetically by enrichment of Mo-Se-Sb and confirmed by the Au versus Ag plots. This type of mineralization is common in a variety of hydrothermal ore systems, such as metasedi- ment-hosted orogenic (e.g., Bendigo-Ballarat; Thomas et al., 2011), Carlin type (e.g., Large et al., 2009) and even VMS (e.g., Mercier-Langevin et al., 2015) deposits.

The second $\mathrm{Au}$ event shows higher gold contents, but is variable in its tenor (Figs. 20, 21). Traverse analyses provide evidence for coupled dissolution-precipitation (CDP) associated with the late fracture set, as is illustrated in fractures 7, 8, 9 of Fig. 11. Thus, the CDP process is related to dissolution of the host and commensurate release of invisible gold from the arsenopyrite structure and its subsequent precipitation as visible gold along fractures. This latter process essentially represents a zone refining processes, as documented by others (e.g., Wagner et al., 2007; Fougerouse et al., 2016a; Wu et al., 2019). In combination, the diffusional process developed by Reich et al. (2006) may have conducted to precipitation of gold nanoparti- 

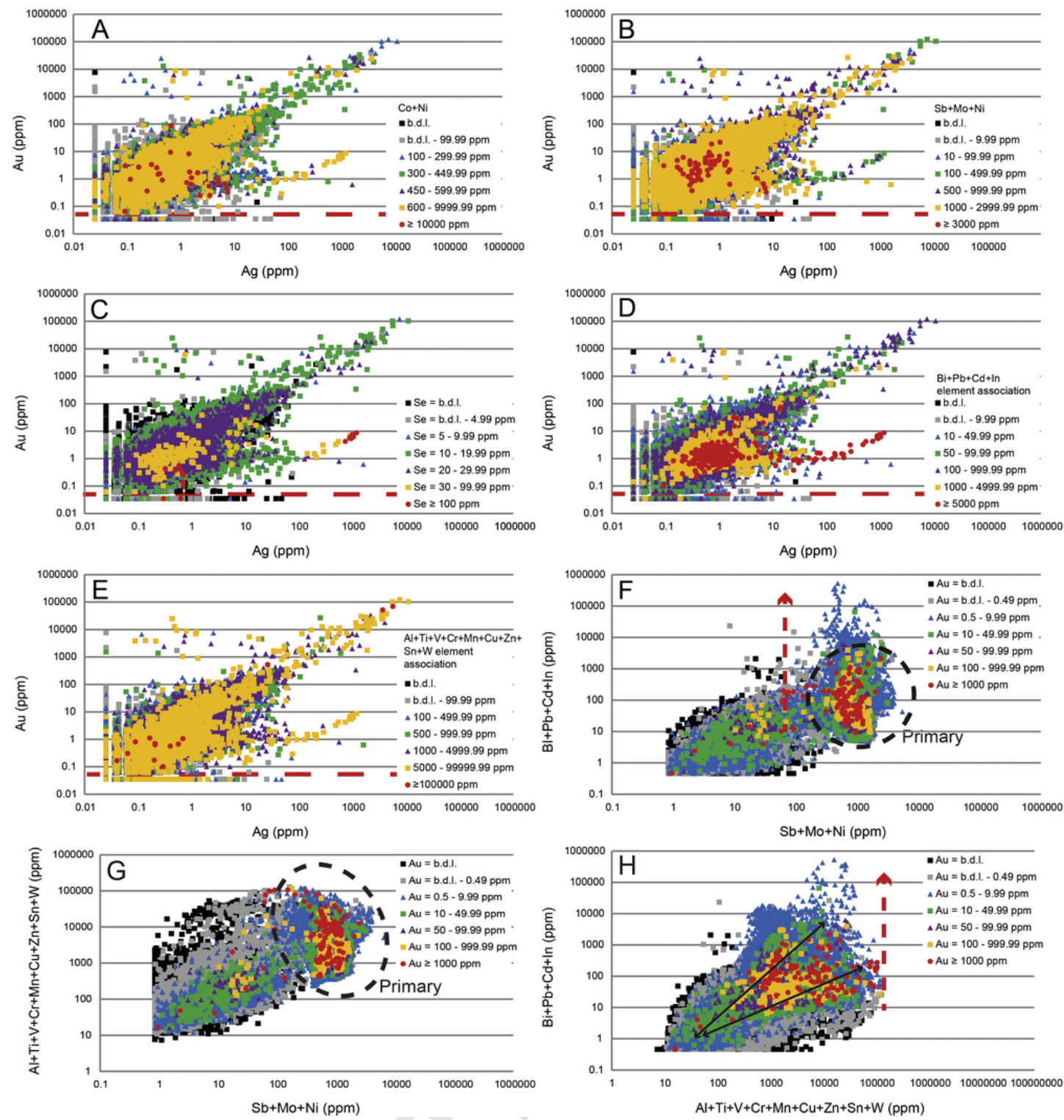

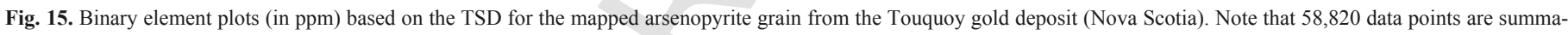

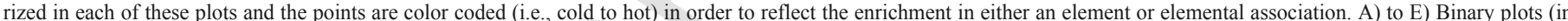

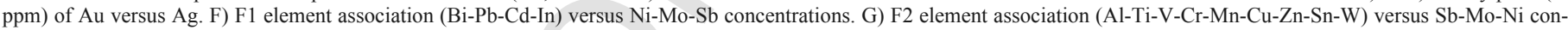

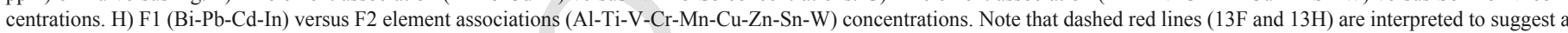

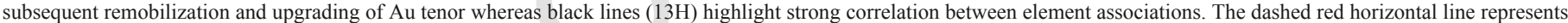
the detection limit for Au. (For interpretation of the references to color in this figure legend, the reader is referred to the web version of this article.)

cles within the arsenopyrite matrix during the early stage of the second metamorphic thermal event prior to remobilization.

Two additional points are noted in the context of these two gold events. Firstly, for both of the events identified, the Au:Ag ratio is uniform at 10:1 in some of the deposits, which is a common value in orogenic gold deposits and must therefore be reflective of a geologically meaningful and relevant process (e.g., Groves et al., 1998; Dubé and Gosselin, 2007; Hastie et al., 2019); this aspect is discussed in more detail below. Secondly, elemental paragenesis and enrichment are very similar in the eight studied deposits (Figs. 12 and 20, respectively) and suggest similar processes and likely similar fluid reservoirs for all of the Meguma gold deposits. We also note in regards to the distribution of Au abundance, based on the tabulation of approximately 300,000 TSD data (Fig. 21), that there are clearly two dis- tinct concentrations of $\mathrm{Au}$ in the arsenopyrite analyzed (i.e., invisible and micro-inclusions).

Independently, the $\mathrm{Au}$ versus $\mathrm{Ag}$ plots show Au-rich versus Ag-poor values (i.e., Figs. 14, 15, 17, 18, 19) which reflect presence of gold micro-inclusions along fracture sets (Fig. 13) or disseminated. As alluded to before, this gold mineralization represents a zone refining process and accompanies mobilization of low-grade invisible gold to form free gold grains.

In addition to the two gold events noted above, a third event is identified based on the Bi-Pb-Cd-In-Ag elemental association in the $\mathrm{Au}-\mathrm{Ag}$ plots and is related to fluid migration along the F1 fracture set. This association has been recognized at most deposits, thus indicating it is common across the Meguma terrane. Importantly, this latter event predates the second gold event (i.e., formation of micro-in- 

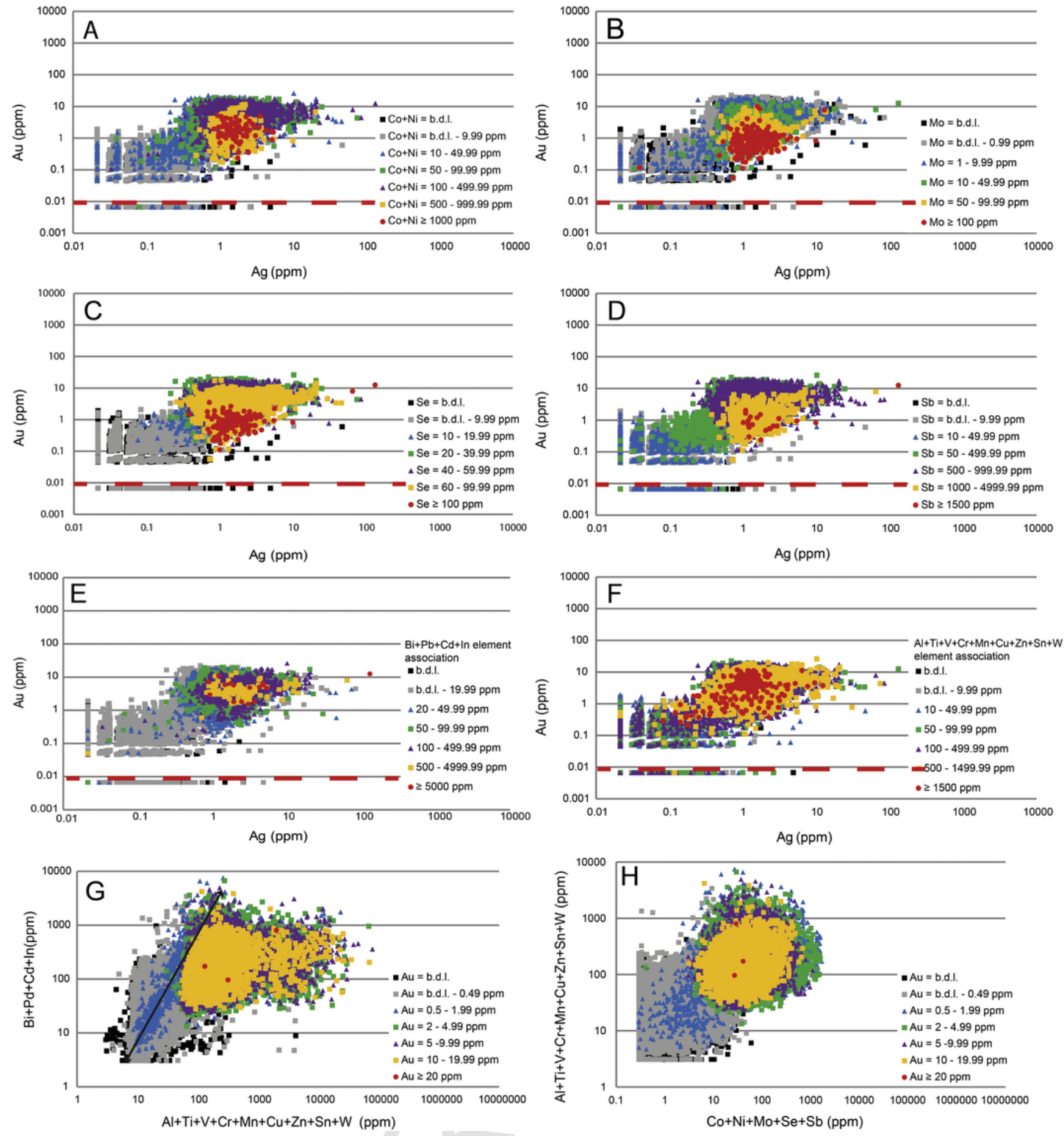

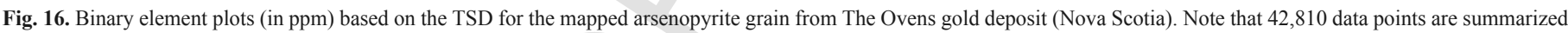

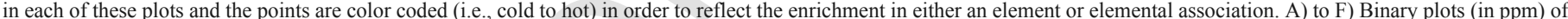

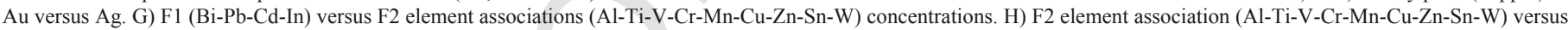

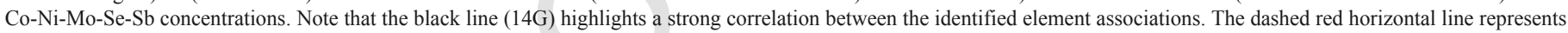
the detection limit for Au. (For interpretation of the references to color in this figure legend, the reader is referred to the web version of this article.)

clusions) and potentially relates to the upgrading of Ag tenors through CDP processes as well (mostly $1000 \mathrm{ppm}$ and up to $10,000 \mathrm{ppm}$ in Dufferin deposit) as fracture fillings. As noted previously, the enrichment of Se in some cases may suggest precipitation of silver selenide (i.e., naumannite), but this remains to be confirmed with future work involving imaging at the nanoscale. Importantly, this event appears not to show Au input and may have had a downgrading effect on the primary gold mineralization. Note that this event shows highly variable Au:Ag ratios (i.e., 1:10, 1:100, 1:1000, 1:10000).

\subsection{Implications of Au:Ag ratios}

As discussed previously, the Au versus Ag plots from the studied deposits indicate that, where best defined by the abundance of data, the two gold events (i.e., primary versus secondary) show similar Au:Ag ratios of 10:1. This observation is consistent with the fact that both gold events likely relate to similar metamorphic processes and similar fluid compositions (i.e., an aqueous carbonic composition, $\mathrm{X}_{\mathrm{CO} 2}=0.10-0.2$ and $5-10 \mathrm{wt} \%$ equiv. $\mathrm{NaCl}$ ), as noted discussed previously (e.g., see review in Kontak and Horne (2010)). Thus, the consistent Au:Ag ratio suggests a similar source, transporting fluid, and chemical conditions for primary gold and similarly for the Au upgrading event which preserves the initial $\mathrm{Au}: \mathrm{Ag}$ ratio during $\mathrm{Au}$ remobilization and its re-precipitation. Moreover, as demonstrated by Cole and Drummond (1986), this ratio can be used as a thermodynamic proxy. Thus, a low temperature $\left(<250{ }^{\circ} \mathrm{C}\right)$, low $\mathrm{Cl}^{-}$content, moderate to high $\mathrm{pH}(\geq 5)$ and high $\Sigma \mathrm{H}_{2} \mathrm{~S} / \Sigma \mathrm{SO}_{4}$ ratio $\left(<10^{5}\right)$ are suggested for the Au-bearing fluids and in addition suggests that 

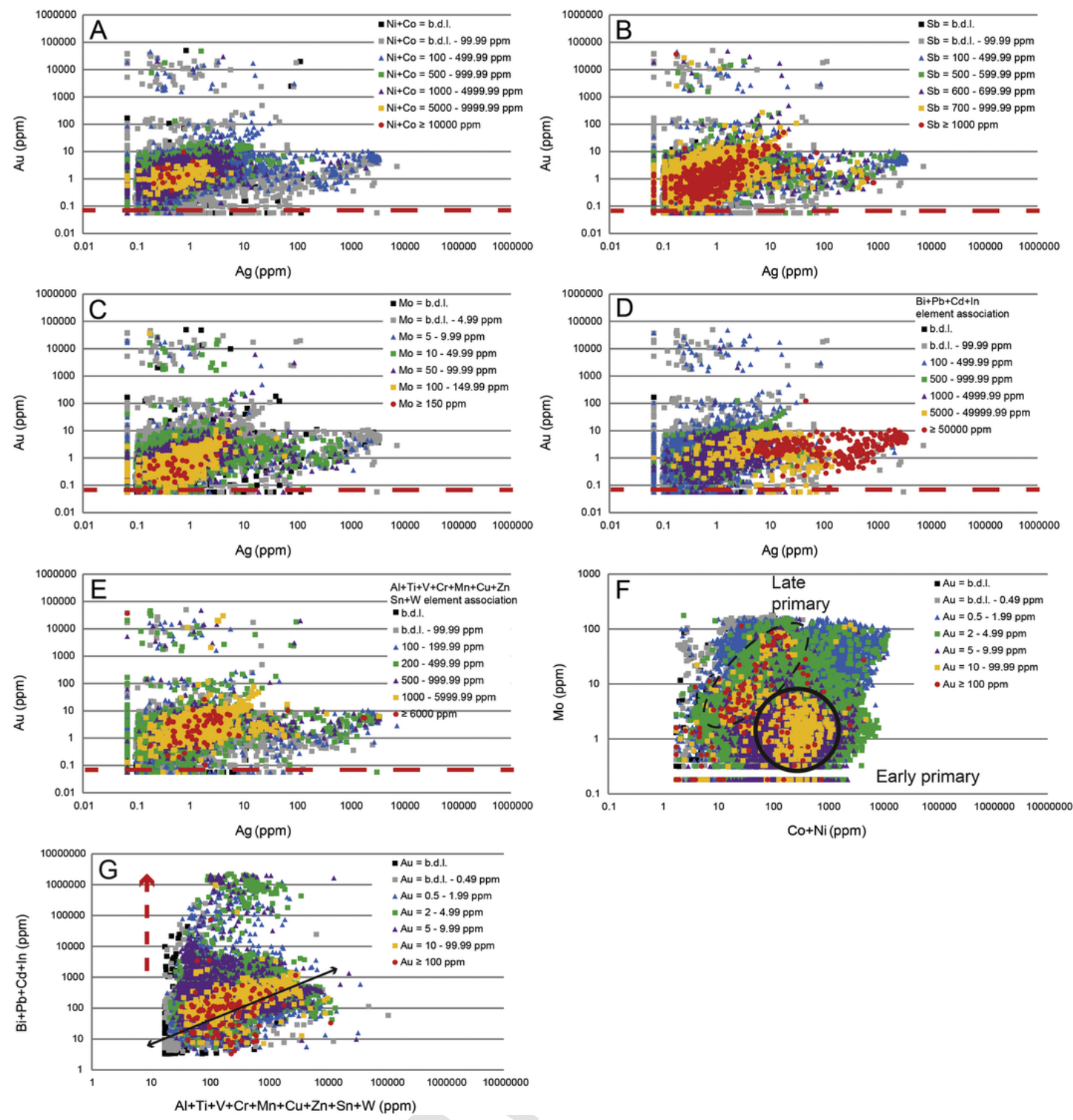

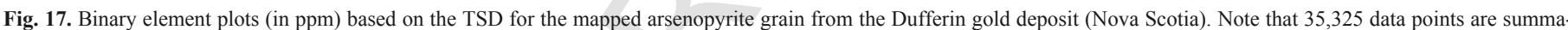

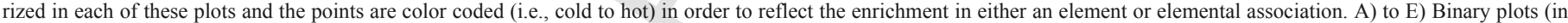

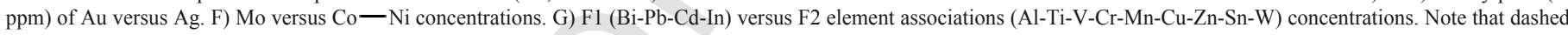

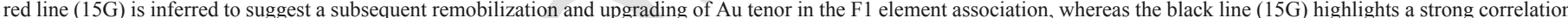

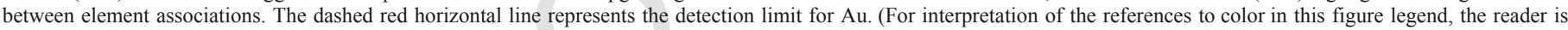
referred to the web version of this article.)

gold was likely transported as an $\mathrm{Au}(\mathrm{HS})_{2}^{-}$complex. Whereas the latter temperature is generally slightly lower than inferred from most of the fluid inclusion studies of the Meguma deposits (i.e., $300-350^{\circ} \mathrm{C}$; see above), the geochemical and isotopic features of the deposits are commensurate with the other parameters.

Independently, the fluid responsible for the $\mathrm{Bi}-\mathrm{Pb}-\mathrm{Cd}-\mathrm{In}-\mathrm{Ag}$ element assemblage shows variable $\mathrm{Au}: \mathrm{Ag}$ ratios that range from 1:10 to $1: 10000$. This Ag event is not associated with new introduction of $\mathrm{Au}$ in the system, but only with remobilization of $\mathrm{Au}$ of the first gold event.

Importantly, it should be noted that the Au:Ag ratios observed could potentially also be influenced by systematic resampling of previously ablated material in the form of ejecta or condensate on the sample surface. However, each dataset includes a minimum of 28,000 data points (i.e., Cochrane Hill dataset) and each deposit shows an in- ternally consistent trend and ratio values. Thus, the demonstrated consistency of the Au:Ag ratios of the analyzed materials is considered to validate the interpretations presented herein.

\subsection{Influence of host rock stratigraphy and other reservoirs}

The influence of the immediate wall rock to mineralized veins and, at a broader scale, the host stratigraphy on the geochemical signature of the mineralizing fluids has previously been discussed for the Meguma gold deposits based on extensive analysis of $\delta^{34} \mathrm{~S}$ for sulfides, $\delta^{13} \mathrm{C}$ and ${ }^{87} \mathrm{Sr} /{ }^{86} \mathrm{Sr}$ for carbonates, $\delta^{18} \mathrm{O}$ for quartz and in-situ LA-ICP-MS trace- element chemistry of carbonates (Kontak and Smith, 1989; Sangster, 1992; Kontak and Kerrich, 1995, 1997; Kontak and Jackson, 1999; Kontak et al., 2011). The $\delta^{34} \mathrm{~S}$ values of sulfides from veins, wall rock and regional stratigraphy show a simi- 

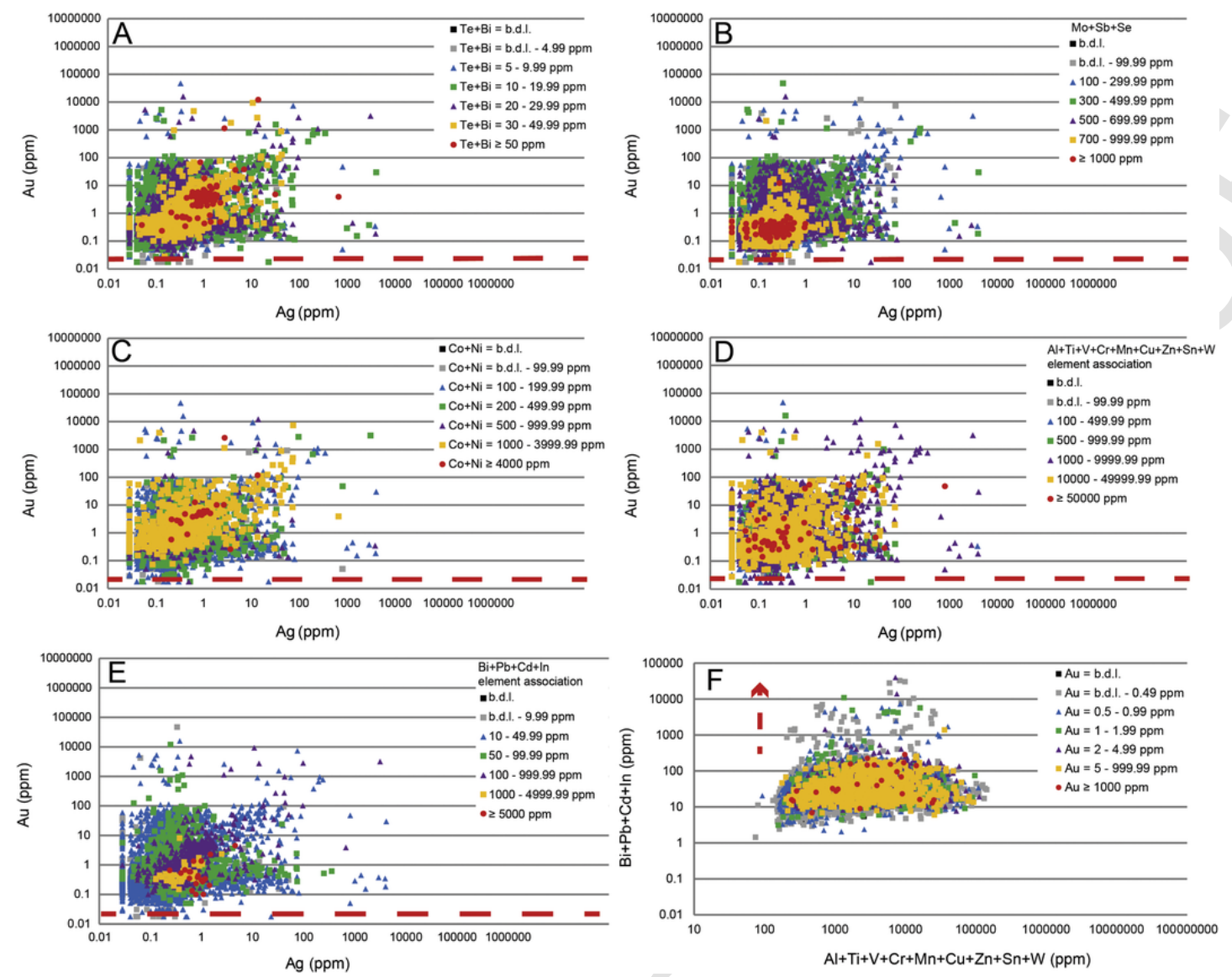

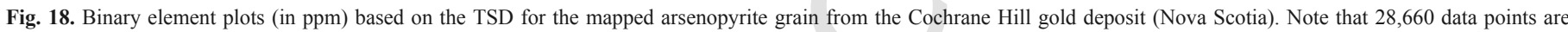

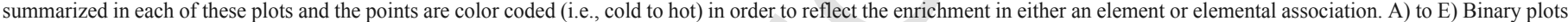

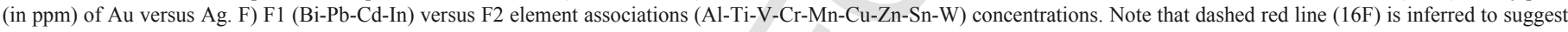

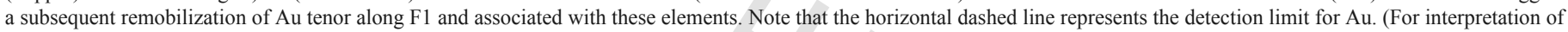
the references to color in this figure legend, the reader is referred to the web version of this article.)

lar systematic increase from +10 to $+30 \%$ and suggest sulfur is locally sourced (i.e., Meguma stratigraphy). In addition, very low $\delta^{13} \mathrm{C}$ values (to ca. $-25 \%$ ) are suggestive of a biogenic carbon source for vein carbonate and, given that this overlaps the signatures for graphite and diagenetic carbonate in the host rocks, this signature also provides a strong case favoring extensive influence of the host stratigraphy. Further evidence of a wall-rock influence is provided from the highly radiogenic Sr signal recorded in some vein carbonates, in addition to an overall upwards increase in $\delta^{18} \mathrm{O}$ for vein quartz which was suggested to reflect an extensive fluid:rock interaction based on modelling (Kontak et al., 2011). Lastly, the trace-element signature of vein carbonate has been interpreted to reflect a variety of influential parameters (e.g., changing T, redox state, mineral assemblages) in addition to different reservoirs including non-Meguma stratigraphy (see discussion in Kontak and Jackson (1999)). All of these observations are consistent with the macro-scale observation of abundant arsenopyrite in both vein and wall rock settings in these deposits demands a source of As, which has been argued to be locally sourced in the carbonand redox-sensitive element-rich black sedimentary wall rocks to the both the Meguma deposits (e.g., Graves and Zentilli, 1982; Smith and Kontak, 1986; Kontak and Smith, 1989; Sangster, 1992) and similar settings elsewhere (Bierlein and Crowe, 2000; Thomas et al., 2011).

In order to further assess the influence of the immediate host stratigraphy on the arsenopyrite geochemistry, a compilation of whole-rock geochemical data from the western part of the Goldenville and Halifax groups (White, 2010) has been used in the Au versus Ag plots already referred to. Referring first to the Au versus Ag plot, we use the Beaver Dam TSD dataset as broadly representative of the Meguma deposits (Fig. 22). As can be seen in the latter diagram, the whole-rock analyses overlap the Ag-rich trend (up to $100 \mathrm{ppm}$ ) with minor $\mathrm{Au}$ as defined by the TSD data. In addition, we have already shown above that this latter trend defines a $\mathrm{Bi}-\mathrm{Pb}-\mathrm{Cd}-\mathrm{In}-\mathrm{Ag}$ element association using the TSD data for arsenopyrite from several Meguma gold deposits. Consequently, this observation suggests that the later stage fluid responsible for this trend and its elemental association may have been strongly influenced by either the Meguma metasedimentary host rocks or a reservoir similar to them geochemically.

\subsection{Implications for gold metallogeny in the Meguma terrane}

It has been noted in earlier discussions of the Meguma gold deposits (e.g., Kontak et al., 1990a, 2011; Kontak and Horne, 2010) that the veins record similar mineralizing fluids on the basis of their low salinities, volatile chemistry $\left(\mathrm{X}_{\mathrm{CO} 2}=0.1-0.2\right)$ and $\delta^{18} \mathrm{O}_{\mathrm{H} 2 \mathrm{O}}$ values, in addition to inferred temperature (ca. $\leq 300-400^{\circ} \mathrm{C}$ ) of formation. These features are noted even though at least two vein forming events are recognized, although the only demonstrated example of an earlier deposits based on absolute dating is The Ovens (Morelli et al., 2005 

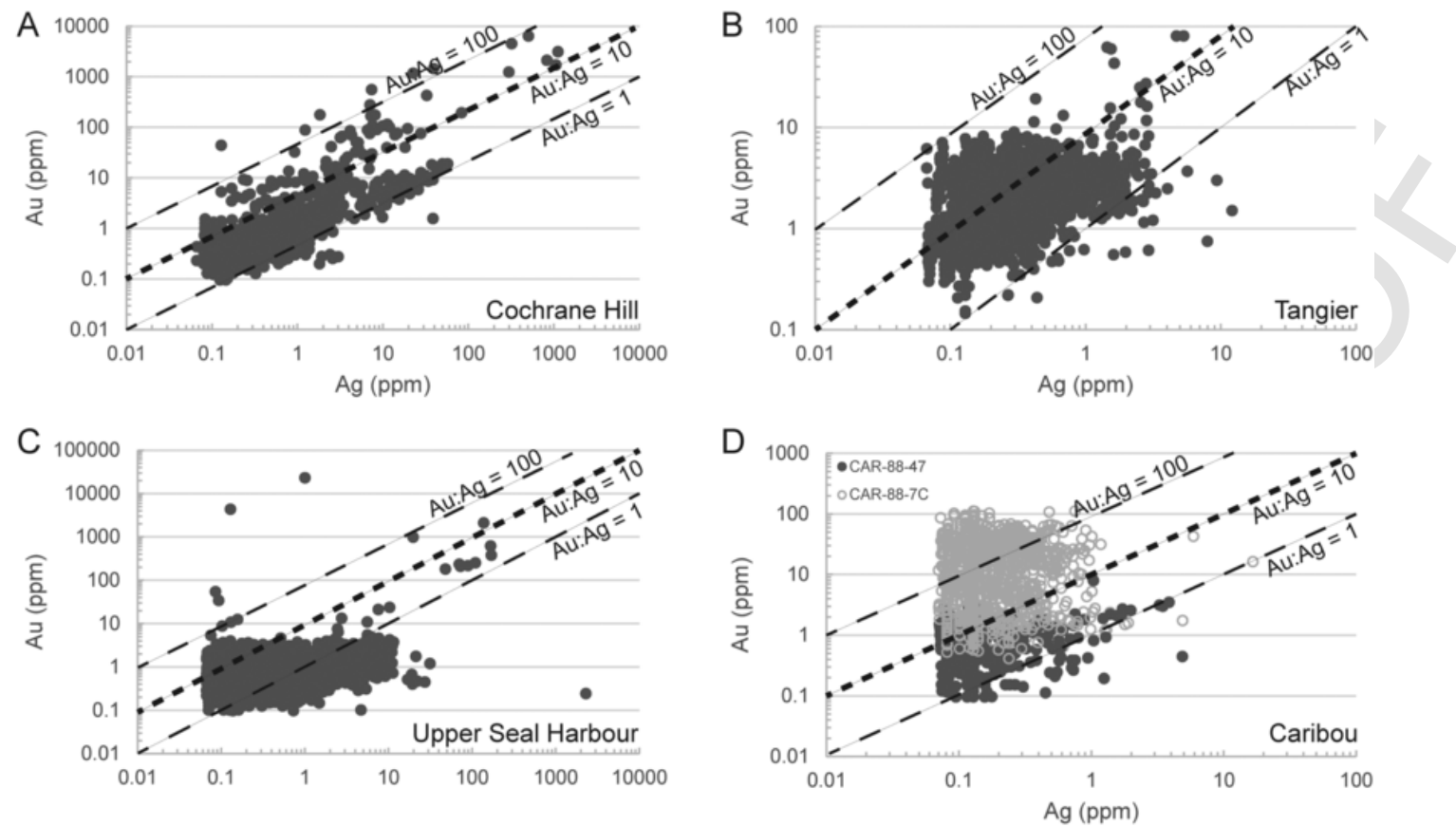

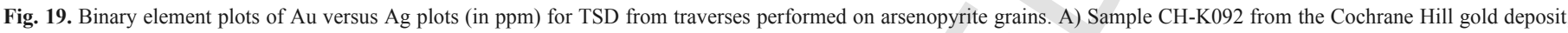

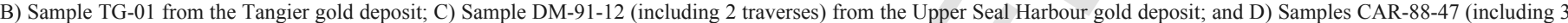

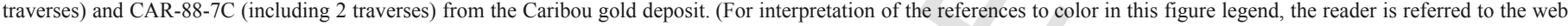
version of this article.)

). These two gold mineralizing events correspond to regional metamorphic and later widespread magmatic processes, respectively. That a similar elemental paragenesis is recorded in the different deposits, which is clearly shown in the summary of elemental paragenesis (Fig. 12), is strong evidence that similar fluids infiltrated these areas even if generated at different times. The arsenopyrite elemental data provide therefore important insight into aspects of the gold metallogeny of these deposits not previously considered. In the first case, the geochemical similarity indicates that if two mineralizing events are indeed present, then a broadly similar fluid in terms of its minor and trace element chemistry can be generated during different tectono-thermal processes. The data also indicate that given that the analyzed samples cover a large area (i.e., $300 \mathrm{~km}$ strike length), the ore-forming process is remarkably similar and thus must reflect processes that are repeatable in time and space.

\section{Conclusions}

Quantitative element distribution maps and traverse analysis of arsenopyrite grains from eight bedding-condordant quartz vein systems in the Lower Paleozoic Meguma gold deposits localized through the Meguma terrane (Nova Scotia, Canada) have been used to a investigate a variety of aspects of these gold deposits. The integration of the element maps, petrography and SEM-EDS imaging and analysis with time slice domain (TSD) provide a new and powerful means to assess elemental paragenesis in these and other gold system globally. Meanwhile, the TSD data provide a means to examine the geochemical signature of the sulfide analyzed and also the chemical evolution of the mineralized system. Importantly, the methodology used in this study is equally applicable to other (i.e., non-gold) hydrothermal ore deposit settings.

In this study elemental paragenesis was first determined for each deposit setting. Results indicate that, despite covering a large geographic area (i.e., $300 \mathrm{~km}$ long) and several deposits, the paragene- sis is similar and hence it follows that like fluids and processes operated across this terrane. Since the samples used reflect two distinct thermo-tectonic events (i.e., regional metamorphism and widespread felsic(-mafic) magmatism), the results imply that fluids with similar metal contents can be generated at more than one time, which has important implications for gold metallogeny.

The use of the TSD provides the means to generate meaningful multi-element diagrams. The $\mathrm{Au}$ versus $\mathrm{Ag}$ plot is used to track $\mathrm{Au}$ mineralization and in this case two or more gold events are recognized. The early gold event has up to $100 \mathrm{ppm} \mathrm{Au}$ present in the sulfides, likely as invisible Au or nanoparticles. The subsequent gold events are recorded by an upgrading due to zone refining of the early $\mathrm{Au}$ with it either having a similar $\mathrm{Au}: \mathrm{Ag}$ ratio or a much higher one. This plot also revealed a distinct $\mathrm{Ag}$ rich event with associated $\mathrm{Bi}-\mathrm{Pb}-\mathrm{Cd}$-In association.

This study represents the first application of LA-ICP-MS mapping to gold metallogeny by studying representative samples across a large part of a gold mineralized terrane. Whereas some of the interpretations may be controversial, the results clearly demonstrate that the method has the potential to provide insight into processes not previously possible. It is hoped that this project provides the impetus for other such studies to be undertaken both in gold deposits and other hydrothermal settings.

Supplementary data to this article can be found online at https:// doi.org/10.1016/j.gr.2019.11.011.

\section{Uncited references}

\section{Acknowledgments}

This work is a continuation of Kontak's ongoing studies of the Meguma gold deposits, which was supported from 1986 to 2006 by the Nova Scotia Department of Natural Resources and in recent years by NSERC Discovery Grants to Kontak. The present study is an out- 

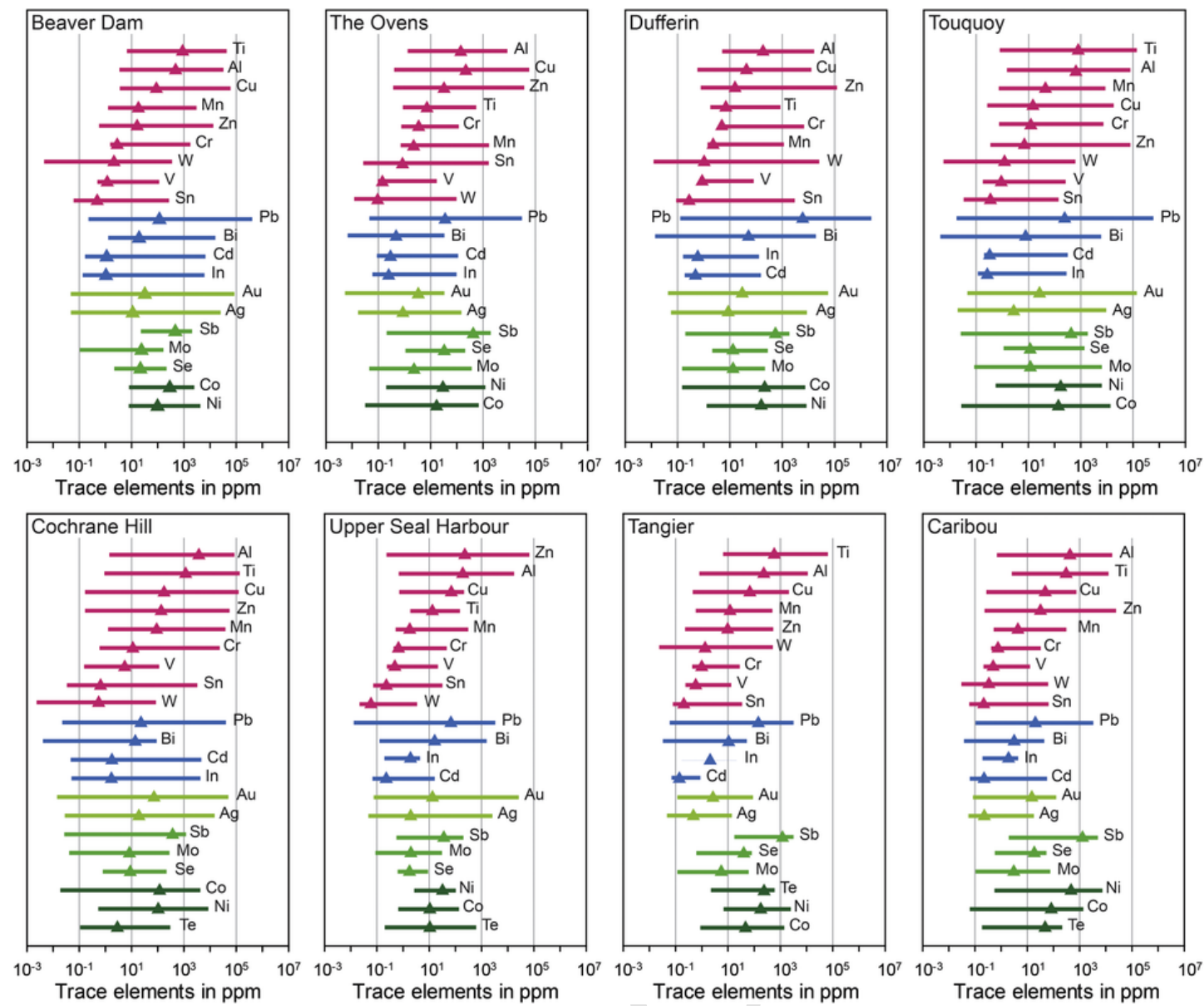

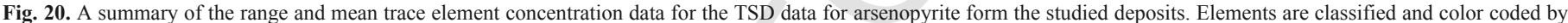

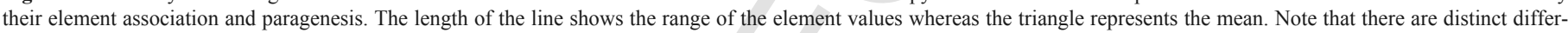
ences in both the mean and range for $\mathrm{Au}$ and $\mathrm{Ag}$ values among the different deposits.

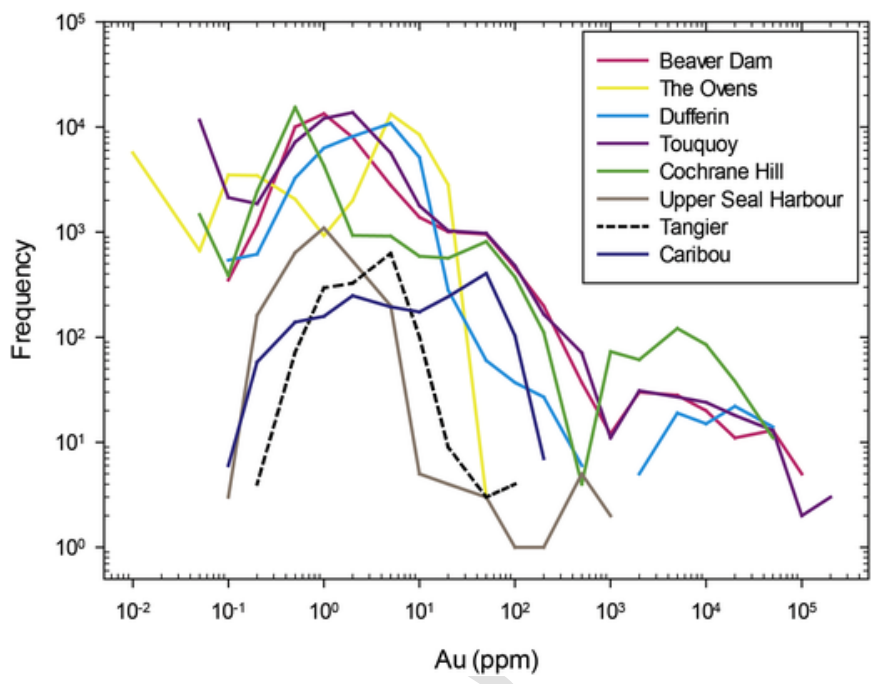

Fig. 21. Frequency of Au concentration (in ppm) in arsenopyrite for the eight studied deposits. Note the very similar trend of gold concentration for all eight samples analyzed at low values (i.e., $<100 \mathrm{ppm}$ ) and that only some of the arsenopyrite grains record high gold values (i.e., $>1000 \mathrm{ppm}$ ). (For interpretation of the references to color in this figure legend, the reader is referred to the web version of this article.) growth of the Geological Survey of Canada's TGI-4 (Targeted Geoscience Initiative) which supported development of the methodology used in this paper (i.e., LA ICP-MS mapping and TSD approach) which were in part presented in earlier contributions by the same authors. We acknowledge that the Touquoy and Beaver Dam samples analyzed were used as part of the MSc thesis project by L. Chen at the University of Alberta. 


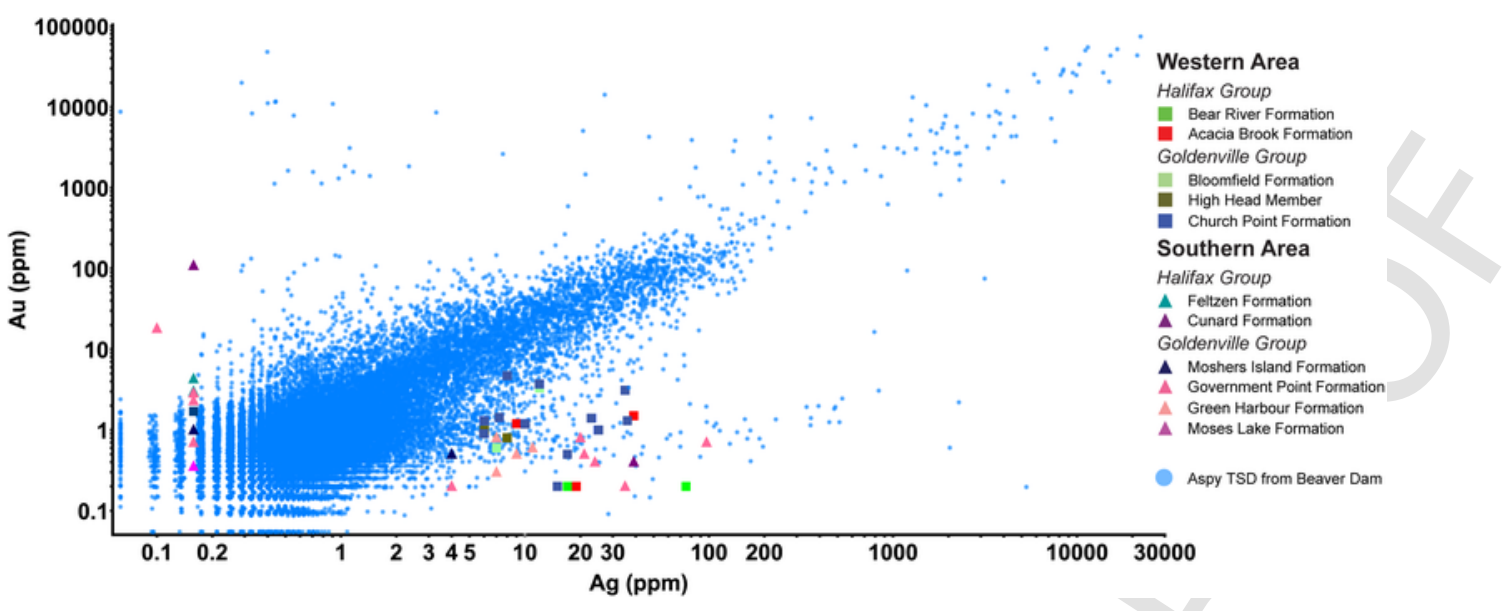

Fig. 22. Binary plot of Au versus Ag (in ppm) for TSD for arsenopyrite from the Beaver Dam deposit ( $n=39,797$; blue points) compared to whole-rock data for the Goldenville and Halifax groups from the western part of the Meguma terrane shown in various colors (see legend; data from White, 2010). Note how the whole-rock data overlap with some of the arsenopyrite data which defines the Ag-rich trend seen in many of the binary Au - Ag plots presented. See the text for further discussion of the significance of this plot. (For interpretation of the references to color in this figure legend, the reader is referred to the web version of this article.)

\section{References}

Augustin, J., Gaboury, D., Crevier, M., 2017. Structural and gold mineralizing evolution of the world-class orogenic Mana District, Burkina Faso: multiple mineralizing events during 150 million years. Ore Geology Reviews 91 (2017), 981-1012.

Bierlein, F.P., Crowe, D.E., 2000. Phanerozoic orogenic lode gold deposits: review. Econ. Geol. 13, 103-139.

Bierlein, F., Smith, P., 2003. The Touquoy Zone deposit: an example of - unusual\| orogenic gold mineralisation in the Meguma terrane, Nova Scotia, Canada. Can. J. Earth Sci. 40, 447-466.

Cathelineau, M., Boiron, M.-C., Holliger, P., Marion, P., Denis, M., 1989. Gold in arsenopyrites; Crystal chemistry, location and state, physical and chemical conditions of deposition. Economic Geology Monograph 6, 328-341.

Chen, L., 2015. Further Re-Os Arsenopyrite Geochronology from Selected Meguma Au Deposits, Meguma terrane, Nova Scotia: Possible Evidence for a Protracted Gold-forming System: Unpublished M.Sc. thesis, Edmonton, Canada, Department of Earth and Atmospheric Sciences University of Alberta, (109 p).

Chen, L., Creaser, R.A., Kontak, D.J., 2014. Further Re-Os arsenopyrite geochronology from selected Meguma Au deposits, Meguma terrane, Nova Scotia: possible evidence for a protracted gold-forming system. Geol. Soc. Am. Abstr. Programs $46,165$.

Clarke, D.B., Chatterjee, A.K., Giles, P.S., 1993. Petrochemistry, tectonic history, and Sr-Nd systematics of the Liscomb Complex, Meguma Lithotectonic Zone, Nova Scotia. Can. J. Earth Sci. 30, 449-464.

Clarke, D.B., MacDonald, M.A., Tate, M.C., 1997. Late-Devonian mafic-felsic magmatism in the Meguma zone, Nova Scotia: Geological Society of America. Memoir 191, 107-127.

Cole, D.R., Drummond, S.E., 1986. The effect of transport and boiling on Ag/Au ratios in hydrothermal solutions: a preliminary assessment and possible implications for the formation of epithermal precious-metal ore deposits. J. Geochem. Explor. 25, $45-79$.

Cook, N.J., Ciobanu, C.L., Meria, D., Silcock, D., Wade, B., 2013. Arsenopyrite-pyrite association in an orogenic gold ore: tracing mineralization history from textures and trace elements. Econ. Geol. 108, 1273-1283.

Atlantic Gold Corporation, 2018. Description and ownership. In: http://www. atlanticgoldcorporation.com/projects/tourquay_gold_project.

Geochim. Cosmochim. Acta

Dostal, J., Keppie, J.D., Jutras, P., Miller, B.V., Murphy, B.J., 2006. Evidence for the granulite-granite connection: Penecontemporaneous high-grade metamorphism, granitic magmatism and core complex development in the Liscomb Complex, Nova Scotia: Canada. Lithos 86, 77-90.

Dubé, B., Gosselin, P., 2007. Greenstone-hosted quart-carbonate vein deposits: Geological Association of Canada. Mineral Deposits Division, Special Publication 5, 49-73.

Dubosq, R., Lawley, C.J.M., Rogowitz, A., Schneider, D.A., Jackson, S.E., 2018. Pyrite deformation and connections to gold mobility: Insight from micro-structural analysis and trace element mapping. Lithos 310-311, 86-104.

Ebertz, G., Clarke, D., Chatterjee, A.K., Giles, P.S., 1991. Chemical and isotopic composition of the lower crust beneath the Meguma Lithotectonic Zone, Nova Scotia: evidence from granulite facies xenoliths. Contrib. Mineral. Petrol. 109, 69-88.
Fougerouse, D., Micklethwaite, S., Tomkins, A.G., Mei, Y., Kilburn, M., Guagliardo, P., Fisher, L.A., Halfpenny, A., Gee, M., Paterson, D., Howard, D.L., 2016. Gold remobilisation and formation of high grade ore shoots driven by dissolution-reprecipitation replacement and $\mathrm{Ni}$ substitution into auriferous arsenopyrite. Geochim. Cosmochim. Acta 178, 143-159.

Fougerouse, D., Reddy, S.M., Saxey, D.W., Rickard, W.D.A., van Riessen, A., Micklethwaite, S., 2016. Nanoscale gold clusters in arsenopyrite controlled by growth rate not concentration: evidence from atom probe microscopy. American Mineralogist 101, 1916-1919.

Gibbons, W., Dig, R., Gordon, T., Murphy, J.B., Reynolds, P., White, J.C., 1996. Mylonite to megabreccia: tracking fault events within a transcurrent terrane boundary in Nova Scotia. Canada: Geology 24, 411-414.

Goldfarb, R.J., Leach, D.L., Miller, M.L., Pickthorn, W.J., 1986. Geology, metamorphic setting, and genetic constraints of epigenetic lode-gold mineralization within the Cretaceous Valdez Group, south-central Alaska. In: Keppie, J.D., Boyle, R.W., Haynes, S.J. (Eds.), Turbidite-Hosted Gold Deposits. vol. 32, pp. 87-105, Geological Association Canada, Special Paper.

Goldfarb, R.J., Baker, T., Dube, B., Groves, D.I., Hart, C.J.R., Gosselin, P., 2005. Distribution, character, and genesis of gold deposits in metamorphic terranes. In: Economic Geology 100th Anniversary Volume. pp. 407-450.

Gourcerol, B., Kontak, D.J., Thurston, P.C., Petrus, J.A., 2018. Gold and trace element distribution in sulfides from mineralized gold Algoma-type BIFs; Implications for nature of mineralizing fluids, metal sources and deposit models. Mineralium Deposita $53,871-894$.

Gourcerol, B., Kontak, D.J., Thurston, P.C., Petrus, J.A., 2018. Application of LA-ICP-MS sulfide analysis and methodology to deciphering elemental paragenesis and associations in addition to multi-stage processes in metamorphic gold settings. Can. Mineral. 56, 1-18.

Graves, M.C., Zentilli, M., 1982. A review of the geology of gold in Nova Scotia. Canadian Institute Mining and Metallurgy Special 24, 233-242.

Greenough, J.D., Krogh, T.E., Kamo, S.L., Owen, J.V., Ruffman, A., 1999. Precise $\mathrm{U}-\mathrm{Pb}$ dating of Meguma basement xenoliths: new evidence for Avalonian underthrusting. Can. J. Earth Sci. 36, 15-22.

Groves, D.I., Goldfarb, R.J., Gebre-Mariam, M., Hagemann, S.G., Robert, F., 1998. Orogenic gold deposits: a proposed classification in the context of their crustal distribution and relationship to other gold deposit types. Ore Geol. Rev. 13, 7-27.

Hastie, E., Kontak, D.J., Lafrance, B., Schindler, M., 2019. Ont the Nature and Origin of Dubéesque Gold in the Abitibi and beyond: GAC-MAC-IAH Conference. Program with Abstract, Québec.

Hicks, R.J., Jamieson, R.A., Reynolds, P.H., 1999. Detrital and metamorphic 40Ar/ 39Ar ages from muscovite and whole-rock samples, Meguma Supergroup, southern Nova Scotia. Can. J. Earth Sci. 36, 23-32.

Horne, R.J., Culshaw, N., 2001. Flexural-slip folding in the Meguma Group. Nova Scotia: Journal of Structural Geology 23, 1631-1652.

Hu, Z., Gao, S., Liu, Y., Hu, S., Chen, H., Yuan, H., 2008. Signal enhancement in laser ablation ICP-MS by addition of nitrogen in the central channel gas. J. Anal. At. Spectrom. 23 (8), 1093-1101.

Jochum, K.P., Weis, U., Stoll, B., Kuzmin, D., Yang, Q., Raczek, I., Jacob, D.E., Stracke, A., Gunther, D., Enzweiler, J., 2011. Determination of reference values for NIST SRM 610-617 glasses following ISO guidelines. Geostand. Geoanal. Res. 35 (4), 397-429. 
Keppie, J.D., 1976. Structural model for saddle reef and associated gold veins in the Meguma Group, Nova Scotia. Nova Scotia Department of Mines and Energy Paper $76-1,(34 \mathrm{p})$

Kerr, M.J., Hanley, J.J., Kontak, D.J., Morrison, G.G., Petrus, J., Fayek, M., Zajacz, Z., 2018. Evidence of upgrading of gold tenor in an auriferous orogenic quartz-carbonate vein system by late magmatic-hydrothermal fluids at the Madrid deposit, Hope Bay Greenstone Belt, Nunavut, Canada. Geochimica et Cosmochimica Acta $241,180-218$.

Kerswill, J.A., 1988. Lithogeochemical indicators of gold potential in the eastern Meguma Terrane of Nova Scotia. In: MacDonald, D.R., Brown, Y. (Eds.), Mines and Minerals Report Activities 1988, Part A, Department of Mines and Energy, Nova Scotia, p. 215-218, Rep, (88-3).

Kerswill, J.A., 1992. Lithogeochemical indicators of gold potential in the eastern Meguma terrane of Nova Scotia: in Sangster, A.L., ed., Mineral Deposit Studies of Nova Scotia Volume 2. Geol. Surv. Can. Pap. 91-2, 19-48.

Kontak, D.J., and Archibald, D.A., 2002, 40Ar/39Ar dating of hydrothermal biotite from high-grade gold ore, Tangier gold deposit, Nova Scotia: further evidence for 370 Ma gold metallogeny in the Meguma terrane: Economic Geology, v. 97, p. $619-628$

Kontak, D.J., and Horne, R.J., 2010, A Multi-stage Origin for the Meguma Lode Gold Deposits, Nova Scotia, Canada: A Possible Global Model for Slate Belt-hosted Gold Mineralization: Gold Metallogeny, p. 58-82.

Kontak, D.J., Jackson, S.J., 1999. Documentation of variable trace and rare earth element abundances in carbonates from auriferous quartz veins in Meguma lode-gold deposits, Nova Scotia. The Canadian Mineralogist 37, 469-488.

Kontak, D.J., Kerrich, R., 1995. Geological and geochemical studies of a metaturbidite-hosted lode gold deposit; the Beaver Dam Deposit, Nova Scotia; II. Isotopic studies: Economic Geology 90, 885-901.

Kontak, D.J., Kerrich, R., 1997. An isotopic (C, O, Sr) study of vein gold deposits in the Meguma terrane, Nova Scotia: implications for source reservoirs. Econ. Geol. 92, 161-180.

Kontak, D.J., Smith, P.K., 1989. Sulphur isotopic composition of sulfides from the Beaver Dam and other Meguma Group-hosted gold deposits, Nova Scotia: implications for genetic models. Can. J. Earth Sci. 26, 1617-1629.

Kontak, D.J., Smith, P.K., Kerrich, R., Williams, P.F., 1990. Integrated model for Meguma Group lode gold deposits, Nova Scotia. Canada: Geology 18, 238-242.

Kontak, D.J., Smith, P., Reynolds, P., Taylor, K., 1990. Geological and 40Ar/39Ar geochronological constraints on the timing of quartz vein formation in Meguma Group lode-gold deposits, Nova Scotia. Atl. Geol. 26, 201-227.

Kontak, D.J., Horne, R.J., Smith, P.K., 1996. Hydrothermal characterization of the West Gore Au-Sb deposit, Meguma terrane. Nova Scotia: Economic Geology 91, $1239-1262$.

Kontak, D.J., Horne, R.J., Sandeman, H., Archibald, D., Lee, J.K.W., 1998. 40Ar/39Ar dating of ribbon-textured veins and wall-rock material from Meguma lode gold deposits, Nova Scotia: implications for timing and duration of vein formation in slate-belt hosted vein gold deposits. Can. J. Earth Sci. 35, 746-761.

Kontak, D.J., Horne, R.J., Kyser, K., 2011. An oxygen isotope study of two contrasting orogenic vein gold systems in the Meguma terrane, Nova Scotia, Canada, with implications for fluid sources and genetic models. Mineral. Deposita 46, 289-304.

Kontak, D., Horne, R., Creaser, R., Petrus, J., Archibald, D., 2013. A petrological and geochronological study of a 360 Ma metallogenic event in Maritime Canada with implications for lithophile-metal mineralization in the Canadian Appalachians. Can. J. Earth Sci. 50, 1147-1163.

Krinov, D.I., 2008. Geochemical zoning of pyrite and arsenopyrite indivuals from the Klyuchevskoe gold deposit. Eastern Transbaikala: Geochemistry International 46 $1005-1015$

Large, R.R., Maslennikov, V.V., Robert, F., Danyushevsky, L.V., Chang, Z., 2007. Multi-stage sedimentary and metamorphic origin of pyrite and gold in the Giant Sukhoi Log Deposit, Lena Gold Province. Russia: Economic Geology 102, 1233-1267.

Large, R.R., Danyushevsky, L., Hollit, C., Maslennikov, V., Meffre, S., Gilbert, S., Bull, S., Scott, R., Emsbo, P., Thomas, H., Singh, B., Foster, J., 2009. Gold and trace element zonation in pyrite using a laser imaging technique: implications for the timing of gold in orogenic and Carlin-style sediment-hosted deposits. Econ. Geol. 104, 635-668.

Lawley, C.J.M., Creaser, R.A., Jackson, S., Yang, Z., Davis, B., Pehrsson, S., Dubé, B., Mercier-Langevin, P., Vaillancourt, D., 2015. Unravelling the Western Churchill Province paleoproterozoic gold metallotect: constraints from Re-Os arsenopyrite and U-Pb xenotime geochronology and LA-ICP-MS arsenopyrite trace element chemistry at the BIF-hosted Meliadine Gold District, Nunavut, Canada. Economic Geology 110, 1425-1454.

Malcolm, W., 1929. Gold fields of Nova Scotia: geological survey Canada. Memoire $156,(253 \mathrm{p})$.

Masurel, Q., Thébaud, N., Allibone, A., André-Mayer, A.S., Hein, K.A.A., Reisberg, L., Bruguier, O., Eglinger, A., and Miller, J., 2019, Intrusion-related affinity and orogenic gold overprint at the Paleoproterozoic Bonikro $\mathrm{Au}-(\mathrm{Mo})$ deposit (Côte d'Ivoire, West African Craton): Mineralium Deposita, v. 104, p. 495-521.

McDivitt, J.A., 2016. Gold Mineralization in the Missanabie-Renabie District of the Wawa Subprovince (Missanabie, Ontario, Canada); M.Sc. thesis, Sudbury, Canada, Laurentian University, (179 p).
Mercier-Langevin, P., Hannington, M.D., Dube, B., Piercey, S.J., Peter, J.M., Pehrsson, S.J., 2015. Precious metal enrichment processes in volcanogenic massive sulphide deposits - a summary of key features, with an emphasis on TIGI-4 research contributions. In: Peter, J.M., Mercier-Langevin, P. (Eds.), Targeted Geoscience Initiative 4: Contributions to the Understanding of Volcanogenic Massive Sulphide Deposit Genesis and Exploration Methods Development: Geological Survey of Canada, Open File. vol. 7853, pp. 117-130.

Morelli, R.M., Creaser, R.A., Selby, D., Kontak, D.J., Horne, R.J., 2005. Rhenium-Osmium geochronology of arsenopyrite in Meguma Group gold deposits, Meguma terrane, Nova Scotia, Canada: evidence for multiple gold-mineralizing events. Econ. Geol. 100, 1229-1242.

Morey, A.A., Tomkins, A.G., Bierlein, F.G., Weinberg, R.F., Davidson, G.J., 2008. Bimodal distribution of gold in pyrite and arsenopyrite: examples from the Archean Boorara and Bardoc shear zones, Yilgarn craton, Western Australia. Economic Geology 103, 599-614.

Müller, W., Shelley, M., Miller, P., Broude, S., 2009. Initial performance metrics of a new custom-designed ArF excimer LA-ICPMA system coupled to a two-volume laser-ablation cell. J. Anal. At. Spectrom. 24, 209-214.

Murphy, J.B., Hamilton, M.A., LeBlanc, B., 2012. Tectonic significance of late Ordovician silicic magmatism, Avalon terrane, northern Antigonish Highlands, Nova Scotia. Canadian Journal of Earth Sciences 49, 346-358.

Newhouse, W.H., 1936. A zonal gold mineralization. Nova Scotia: Economic Geology $31,805-831$.

Neyedley, K., Hanley, J.J., Fayek, M., Kontak, D.J., 2017. Textural, fluid inclusion, and stable $\mathrm{O}$ isotope constraints on vein formation and gold precipitation, $007 \mathrm{de}-$ posit, Bissett, Manitoba, Canada. Econ. Geol. 112, 629-660.

Owen, J.V., Greenough, J.D., 1991. An empirical sapphirine-spinel Mg-Fe exchange thermometer and its application to high grade xenoliths in the Popes Harbour dyke, Nova Scotia, Canada. Lithos 26, 317-332.

Owen, J.V., Greenough, J.D., Hy, C., Ruffman, A., 1988. Xenoliths in a mafic dyke at Popes Harbour, Nova Scotia: implications for the basement to the Meguma Group. Can. J. Earth Sci. 25, 1464-1471.

Paton, C., Hellstrom, J., Paul, B., Woodhead, J., Hergt, J., 2011. Iolite: Freeware for the visualisation and processing of mass spectrometric data. J. Anal. At. Spectrom. $26,2508-2518$.

Poulsen, K.H., Robert, F., Dubé, B., 2000. Geological classification of Canadian gold deposits: Geological survey of Canada. Bulletin 540, (106 p).

Reich, M., Kesler, S.E., Utsunomiya, S., Palenik, C.S., Chryssoulis, S.L., Ewing, R.C., 2005. Solubility of gold in arsenian pyrite. Geochim. Cosmochim. Acta 69 , 2781-2796.

Reich, M., Utsunomiya, S., Kesler, S.E., Wang, L., Ewing, R.C., Becker, U., 2006. Thermal behavior of metal nanoparticles in geologic materials. Geology 34 , 1033-1036.

Ryan, R.J., Smith, P.K., 1998. A review of the mesothermal gold deposits of the Meguma Group, Nova Scotia, Canada. Ore Geology Reviews 13, 153-183.

Sangster, A.L., 1992. Light stable isotope evidence for a metamorphogenic origin for bedding-parallel, gold-bearing veins in the Cambrian flysch, Meguma Group, Nova Scotia. Exploration and Mining Geology 1, 69-79.

Sangster, A.L., Smith, P.K., 2007. Metallogenic summary of the Meguma gold deposits, Nova Scotia. In: Goodfellow, W.D. (Ed.), Mineral Deposits of Canada: A Synthesis of Major Deposit-Types, District Metallogeny, the Evolution of Geological Provinces, and Exploration Methods: Geological Association of Canada Special Publication No. 5. pp. 723-732.

Scallion, K.L., Jamieson, R.A., Barr, S.M., White, C., Erdmann, S., 2011. Texture and composition of garnet as a guide to contamination of granitoid plutons: an example from the Govenor Lake area, Meguma terrane. Nova Scotia: Canadian Mineralogist 49, 441-458

Shore, M., Fowler, A.D., 1996. Oscillatory zoning in minerals: a common phenomenon. Can. Mineral. 34, 1111-1126.

Smith, P.K., Kontak, D.J., 1986. Meguma gold studies: advances in geological insight as an aid to gold exploration. In: Bates, J. (Ed.), Nova Scotia Department of Mines and Energy Open House. vol. 12, pp. 105-114, Program and Summaries: Information Series $\mathrm{n}$.

van Staal, C.R., 2007. Pre-Caroniferous tectonic evolution and metallogeny of the Canadian Appalachians. In: Goodfellow, W.D. (Ed.), Mineral Deposits of Canada: A Synthesis of Major Deposit-Types, District Metallogeny, the Evolution of Geological Provinces, and Exploration Methods: Geological Association of Canada, Mineral Deposits Division, Special Publication. vol. 5, pp. 793-818.

Sylvester, P.C., Cabri, L.J., Turbett, M.N., McMahon, G., Laflamme, J.G.H., Peregoedova, A., 2005. Synthesis and Evaluation of a Fused Pyrrhotite Standard Reference Material for Platinum-Group Element and Gold Analyses by Laser Ablation-ICPMS: Geological Survey of Finland, Espoo, Finland, 16-20, 10th International Platinum Symposium; Platinum-Group Elements; from Genesis to Beneficiation and Environmental Impact, (Extended Abstracts).

Thomas, H.V., Large, R.R., Bull, S.W., Maslennikov, V., Berry, R.F., Fraser, R., Froud, S., Moye, R., 2011. Pyrite and pyrrhotite textures and composition in sediments, laminated quartz veins and reefs at Bendigo gold mine, Australia: insights for ore genesis. Econ. Geol. 106, 1-31.

Wagner, T., Klemd, R., Wenzel, T., Mattson, B., 2007. Gold upgrading in metamorphosed massive sulfide ore deposits: direct evidence from laser-ablation-induc- 
tively coupled plasma-mass spectrometry analysis of invisible gold. Geology 35 (9), 775-778.

White, C.E., 2010. Compilation of geochemical and petrographic data from the western and southern parts of the Goldenville and Halifax groups, Nova Scotia: Depart ment of Natural resources. In: Mineral Resources Branch Open File Report ME 2010-1, (9 p).

White, C.E., Barr, S.M., 2010. Lithochemistry of the Lower Paleozoic Goldenville and Halifax groups, southwestern Nova Scotia, Canada: Implications for stratigraphy, provenance, and tectonic setting of the Meguma terrane: Geological Society of America. Memoir 206, 347-366.

White, C.E., Palacios, T., Jensen, S., Barr, S.M., 2012. Cambrian-Ordovician acritarchs in the Meguma terrane, Nova Scotia, Canada: resolution of early Paleozoic stratigraphy and implication for paleography. Bull. Geol. Soc. Am. 124, 1773-1792.

White, C.E., Scallion, K., Barr, S.M., and Jamieson, R.A., 2009, Geology of the Governor Lake area ('Liscomb Complex'), Meguma terrane, Nova Scotia, Canada [abs.]: Geological Association of Canada-Mineralogical Association of Canada Annual Meeting, Program with Abstracts, CD-Rom

Williams, H., 1995. Introduction: chapter 1 in geology of the Appalachian Caledonian Orogen in Canada and Greenland: Geological Survey of Canada. Geology of Canada 6, 1-19.
Wohlgemuth-Ueberwasser, C.C., Jochum, K.P., 2015. Capability of fs-LA-ICP-MS for sulphide analysis in comparison to ns-LA-ICP-MS: Reduction of laser induced matrix effects? : The. J. Anal. At. Spectrom. 30, 2469-2480.

Woodhead, J., Hellstrom, J., Hergt, J., Greig, A., Maas, R., 2007. Isotopic and elemental imaging of geological materials by laser ablation inductively coupled plasma mass spectrometry. J. Geostand. Geoanal. Res. 31, 331-343.

Wu, Y.-F., Li, J.-W., Evans, K., Koenig, A.E., Li, Z.-K., O'Brien, H., Lahaye, Y., Rempel, K., Hu, S.-Y., Zhang, Z.-P., Yu, J.-P., 2018. Ore-forming processes of the Daqiao epizonal orogenic gold deposit, West Qinling Orogen, China: constraints from textures, trace elements, and sulfur isotopes of pyrite and marcasite, and Raman spectroscopy of carbonaceous material. Economic Geology 113, 1093-1132.

Wu, Y.-F., Evans, K., Li, J.-Y., Fougerouse, D., Large, R., Guagliardo, P., 2019. Metal remobilization and ore-fluid perturbation during episodic replacement of auriferous pyrite from an epizonal orogenic gold deposit. Geochimica et Cosmochimica Acta $245,98-147$.

Zhao, H.Z., Frimmel, H.E., Jiang, S.-Y., Dai, B.-Z., 2011. LA-ICP-MS trace element analysis of pyrite from the Xiaoqinling gold district, China: implications for ore genesis. Ore Geol. Rev. 43, 142-153. 